\title{
OBSCENITY IN THE MAILS: A COMMENT ON SOME PROBLEMS OF FEDERAL CENSORSHIP*
}

\author{
James C. N. Paul† and Murray L. Schwartz $\ddagger$
}

Recent decisions of the Supreme Court dealing with the constitutionality of restraints on circulation of obscenity have served, paradoxically, to clarify and to underscore vexing questions in this field of law. Even more recent decisions of lower federal courts suggest the need for broad-gauged re-appraisal of federal censorship of obscenity in the mails. ${ }^{1}$

This paper constitutes a brief "interim" report on a broader study of that subject. The discussion traces in outline the development of

* This paper is based upon a study of "censorship" of the mails conducted under the auspices of the Institute of Legal Research of the University of Pennsylvania Law School. The study has been financed by the Fund for the Republic, Inc. The authors have acted as co-directors of the project. Research for the study included, among other things, field investigations of postal and customs operations in Washington, New York, Philadelphia, Chicago, St. Paul, Minneapolis, Los Angeles and San Francisco; officials responsible for enforcement of the laws under study were interviewed and appropriate file material was examined. Space here precludes a detailed breakdown of this work or expression of individual thanks to the persons in government who without exception extended cordial assistance to our work. But particular acknowledgment must be made of the interest and help extended by $\mathrm{Mr}$. Abe M. Goff, General Counsel of the Post Office, Mr. William C. O'Brien, Assistant General Counsel, Mr. James C. Haynes, Chief Hearing Examiner of the Post Office, Mr. David H. Stephens, Chief of Postal Inspection Service, and to Mr. Huntington Cairns, General Counsel to the National Gallery of Art, Mr. Irving Fishman, Deputy Collector of Customs of the Port of New York, who all extended more hospitality and assistance than we had any right to expect. A number of attorneys and other persons connected with cases involving enforcement of the postal and customs laws have also extended very gracious help. We owe a particular debt to Morris L. Ernst, Esq., which we are glad to acknowledge.

$\dagger$ Associate Professor of Law, University of Pennsylvania. LL.B., University of Pennsylvania Law School, 1951.

† LL.B., University of Pennsylvania Law School, 1950. Member, Philadelphia bar.

1. See, e.g., Sunshine Book Co. v. Summerfield, 26 U.S.L. WEEK 2169 (D.C. Cir. Oct. 3, 1957) (Court of Appeals divided 5 to 3 on validity of postal order barring nudist magazines from mails; the dissenters argued that the order "is of highly doubtful [constitutional] validity." A petition for certiorari has been filed in this case). One Inc. v. Olesen, 241 F.2d 772 (9th Cir. 1957) (sustaining postal order barring an issue of the magazine One, a serious publication for homosexuals, from the mails. A petition for certiorari to the Supreme Court is now pending in this case 26 U.S.L. WEEK 3071 (U.S. Aug. 27, 1957) (No. 290)). See also discussion infra, of the litigation over seizure of erotica imported by the late Professor Kinsey. And see Times Film Corp. v. City of Chicago, 244 F.2d 432 (7th Cir. 1957) (upholding city censorship ban of the film Game of Love against contention that ordinance on its face and as applied, violates first amendment. A petition for certiorari has been granted and the decision below reversed unanimously. The Court's decision apparently on the merits of the issue of obscenity vel non was rendered after the Justices, ex parte, reviewed the film. See The New York Times, Nov. 14, 1957, p. 40, col. 1). 
obscenity law-particularly federal law-and describes some aspects of contemporary postal and customs censorship. It then analyzes some problems involved in defining and justifying restraints on obscenity circulation and explores the recent contributions of the Supreme Court and American Law Institute in that regard. Finally, it briefly describes some proposals to be explored in more detail in our study.

\section{DeVELOPMENT OF THE LAW}

Since 1842 there have been federal statutes in this country authorizing federal officials to confiscate obscene matter. The first law dealt solely with importations from abroad and proscribed only "prints," "paintings," "lithographs" and other pictorial matter." When it was enacted there was very little anti-obscenity law in Anglo-American jurisprudence ${ }^{3}$ and no "censorship" statutes-laws allowing government officials to exert administrative "prior restraints" against circulation of all things deemed by them to be "obscene." 4

The common law did sanction punishment for the exhibition of some "obscene" creations, though prior to the nineteenth century the contours of the offense appear vague. The crime seems to have been lumped with other public affronts against morality-open lewdness, cursing and blasphemy; thus, the outrageousness of the defendant's public conduct was the gist of the wrong. In the nineteenth century, however, obscenity law developed as a field apart, and there occurred a subtle but basic shift of emphasis. Whereas conduct-the defendant's

2. 5 STAT. 566,567 (1842). The statute provided for an in rem libeling procedure in the district court whereby contested seizures would be adjudicated by a judge and jury. See United States v. Three Cases of Toys, 28 Fed. Cas. 112, No. 16499 (S.D.N.Y. 1843).

3. The earliest meaningful American cases seem to be: Knowles v. State, 3 Day (Conn.) 103 (1808); Commonwealth v. Holmes, 17 Mass. 336 (1821) ; State v. Appling, 25 Mo. 315 (1857); Commonwealth v. Sharpless, 2 S. \& R. (Pa.) 91 (1815). See also REV. STAT. MASS. c. 130, § 10 (1836) (punishing publication of obscene materials). See Wharton, Criminal Law 739 (2d ed. 1852). For English source material reflecting the status (and lack of it) of "obscenity law" at various periods of history, see, e.g. Queen v. Read, 11 Mod. 142, 88 Eng. Rep. 953 (1708); Rex v. Curl, 2 Str. 788, 93 Eng. Rep. 849 (1727); HawkINs, PlEAS of the Crown 355 (Leach ed. 1788); Vagrancy Act, [1824] 5 Geo. 4 c. 83, § 4; StePHEN, DiGEST of Criminal Law 117 (4th ed. 1887). See Scott, Into Whose Hands (1945), for detailed historical discussion.

4. Indeed it is interesting to note that even during the Tudor-Stuart licensing era when censorship was in theory total, there seems to have been no standard or particular focus on obscenity as we know the concept today. Elizabethan and Restoration drama reflects many instances of bawdiness that goes pretty far for modern audiences. Prynne's Histriomastix and Jeremy Collier's Short View of Profaneness bear testimony to the fact that there was much that was shocking to 16th and 17th century audiences and also to the fact that little by way of law enforcement was done to suppress it. The famous Vizetelly Memorandum, a protest written to the Treasury Department after works by Zola were banned, lists in great detail titles and citations to the "obscenity" of the Elizabethan and Restoration dramatists. Excerpts are reprinted in ERNST \& SEAGLE, To THE PURE 315-18 (1929). 
public use of obscenity-was formerly the apparent basis of prosecution, it now became a subordinate element; obscenity was bad per se, ${ }^{5}$ and virtually any distribution, regardless of motive, audience reached or actual harm done, was proscribed.

Just one hundred years ago Lord Chief Justice John Campbell startled the House of Lords with a lurid report: "Bales" of printed material-"poison more deadly than arsenic"-were secreted in various London houses whence the stuff was being distributed and hawked in back alleys and dingy shops around Holywell Street. Campbell proposed a law to suppress this trade-his famous Obscene Publications Act-which proscribed all circulation of things deemed obscene.

It was enacted, ${ }^{6}$ despite sharp debate that foreshadowed problems to come: What, demanded opponents, is the definition of an "obscene" book? (The bill supplied none, nor, of course, did the common law.) Would it be criminal for a respectable bookseller to sell a bawdy Restoration "classic" to a respectable gentleman just because the work happened to fit the definition, whatever it was? Trust the good sense of the courts and those who enforce the law, was the response, reinforced with vigorous pleas for vigorous laws to deal with the Holywell peddlers.

Ten years later Lord Cockburn, speaking for the Queen's Bench in the famous Hicklin case, ${ }^{7}$ defined obscenity: "The test" was whether the "tendency of the matter is to deprave and corrupt those whose minds are open to immoral influences and into whose hands a publication of this sort may fall." 8 Thus, the law became concerned with "mental sanitation" of sex expression in the arts.

These English developments-Campbell's Act and Cockburn's "test"- -are of interest because they reflect historically the first real development of "anti-obscenity" law. The same pattern unfolded in this country: Legislatures enacted statutes; courts, sometimes with unthinking acquiescence, read the Hicklin standard into them, verbatim.

5. It would appear for example that "anti-vice" societies were very much a product of the nineteenth century. Notable examples include the English Society for the Suppression of Vice, the New York Society for the Suppression of Vice and the New England Watch and Ward Society. For an interesting protest against early efforts at ant1-vice society book censorship in England, see 13 EDINBURGH REv. 333 (1809). The First International Congress against obscene literature was held in Switzerland in 1893. See 57 THE NATION 323 (1893). Thereafter such gatherings became regular occurrences. For history of the development during the nineteenth century of the copyright doctrine prohibiting court recognition of property rights in immoral works, and for examples of extreme, rather "strait-laced" judical pronouncements applying this doctrine, see Rogers, Copyright and Morals, 18 Mict. L. Rev. 390 (1920).

6. [1857] 20 \& 21 VICT. c. 83. For the accounts of the debates and passage of Lord Campbell's Obscene Publications Act, see 145-49 PARL. DEB. (3d ser. (1857)). For a further contemporary comment, see Lord Broughham's unsigned, hostile article in 3 LAw MAGAZINE \& LAW REv. 283 (1857).

7. L.R. 3 Q.B. 360 (1868).

8. See 17 STAT. 598 (1873); L.R. 3 Q.B. 360,362 (1868). 
Not until 1873 did the federal government really enter the field. ${ }^{\circ}$ Then, Anthony Comstock, agent for the newly formed New York Society for the Suppression of Vice, descended on Congress and waged a one-man lobbying campaign, one of the most effective of its kind on record, to push through an omnibus federal anti-obscenity bill, including a statute on importation, a statute on distribution of obscene matter in federal territories and the postal statute which is sometimes still referred to by his name." (Indeed, Comstock frequently called it "my bill.") And in 1879, in the notorious Bennett case, 11 a crusty old crank who published free love tracts was sent to jail, and a Hicklin gloss put upon Comstock's act; the law was made to read as if it said in terms: No one shall publish or receive, via the mails, anything which may tend to corrupt, sexually, the corruptible.

The debates which attended passage of the Comstock Act reflect only one thing for sure: Congress was in such a hurry to pass the law-the adjournment hour was pressing-that few congressmen had much familiarity with the terms of the bill. In retrospect it is too bad a few more questions and answers weren't spread upon the record, because, arguably, it is possible that Congress never meant to give the Post Office the independent censorship power which it soon assumed. The statute said in effect, "obscene" things "shall [not] be carried" in the mails; it then provided penalties for those who "knowingly" sent or received it. Arguably it was drafted as a criminal statute. The textual structure (viz: obscenity shall not be conveyed and those who knowingly mail it shall be punished) was very similar to an earlier statute, the Act of 1865 ; and it is plain that, this earlier statute was intended solely as a criminal statute. But apparently after 1873 postal authorities inferred, despite the absence of express suggestion to that

9. The first postal statute on obscenity was enacted in 1865 after very little debate. 13 Stat. 504 (1865). It was a criminal statute, aimed at individuals who were supplying soldiers with obscenity. The wording in substance (though not in detail) was quite similar to the act of 1873 . The short Senate debates attending its passage made it very clear, however, that the Senate intended it to be only a criminal statute. See Cong. GloBe, 38th Cong., 2d Sess. 450, 654, 660-62, 965-66 (1865). For accounts of Comstock's activity in securing passage of the act of 1873, see Broun \& LEECH, AnтноNy Comstock (1927) which relies on, and quotes extensively from Comstock's own diary. For the legislative sources, see Cong. Globe, 42d Cong., 3d Sess. 1240, $1307,1358,1371,1436,2004$ (1873). See also De Grazia, Obscenity and the Mail: $A$ Study of Administrative Restraint, 20 LAW \& CoNTEMP. PROB. 608 (1955).

10. It is now 18 U.S.C. $\$ 1461$ (1956). The Comstock Act is a verbose statute; it also covers abortifacient and "filthy" matter which are considered as non-mailable categories apart from obscenity and subject to different standards. See United States v. Limehouse, 285 U.S. 424 (1932); Consumers Union v. Walker, 145 F.2d 33 (D.C. Cir. 1944).

11. United States v. Bennett, 24 Fed. Cas. 1093, No. 14571 (2d Cir. 1879). For the influence of the Bennett case, see Rosen v. United States, 161 U.S. 29 (1896). The Comstock Act was declared to be constitutional in the sweeping dicta of Ex parte Jackson, 96 U.S. 727 (1878). 
effect in the debates, the additional authorization to exercise an independent civil program to enforce the proscription. ${ }^{12}$

In any event, a federal censorship operation was developed over the years. Mail deemed "obscene" was stopped in transit. The sender might be prosecuted: that was up to the Justice Department. But regardless of the criminality of the mailing or whether the United States attorney agreed that it was obscene, the Post Office exercised the power to ban any book offensive to its interpretation of the standards.

Since Congress had defaulted on the definition of obscenity and the courts seemed to sanction indiscriminate use of the Hicklin formula, the law was enforced, not only against pornography, but also against illustrious creations of human expression. One federal judge opined that even the Bible might be "obscene," and a customs official confiscated a copy of Michelangelo's Sistine Chapel rendition of the Last Judgment. ${ }^{13}$ Postal and customs censors in Washington proscribed works by Ovid, Apuleus, Aristophanes, Rabelais, Boccacio, Voltaire, Benjamin Franklin, Anatole France, James Joyce, Havelock Ellis, and Freud. $^{14}$

12. A recodification of the statute in 1876 declared that obscenity was "nonmailable" and was not to be "conveyed" or "delivered" by the Post Office. 19 STAT. 90 (1816). This implies a "censorship" power, but if so it was bestowed with no debate over the problem by Congress.

The point stressed here is not that the Post Office is today acting illegally. The long period of congressional silence plus recodifications which more plainly imply an independent civil censorship sanction, plus congressional augmentation of this power (e.g., by enactment of 39 U.S.C. $\$ 259(\mathrm{a})$ ), plus court approval, sub silentio, of the independent postal censorship power have put a gloss on the statute. In the recent case of Sunshine Book Co. v. Summerfield, 26 U.S.L. WEEK 2169 (D.C. Cir. Oct. 3, 1957), a divided full bench of the Court of Appeals for the District of Columbia upheld the statutory power of the Post Office to stop "obscene" mail in transit, though three dissenters doubted whether the Comstock Act really does authorize this power and if so whether it is constitutional.

The point stressed here is that when Congress enacted the Comstock Act, apparently no real thought was given to the question whether the statute authorized an independent "censorship" program as well as criminal enforcement of the proscription. There was a fleeting objection to customs censorship when Senator Casserly, pointing to the expansion of the importation prohibition to cover "obscene books," voiced doubts as to "whether it can be left to officers of the Customs House to determine what kind of literature .... is to be admitted." This objection was withdrawn, apparently when the Senator learned that all material seized by customs officers was to be produced in court for in rem, libel proceedings, thus curtailing (in theory) the scope of administrative discretion. Cong. GLOBE, 42d Cong., 3d Sess. 1436 (1873).

Compare the discussion of earlier postal legislation, cited in note 9 supra, and note that apparently neither the act of 1865 nor the recodification of 1872,17 Stat. 302 , was intended as a civil, "censorship" type statute; yet the Comstock Act followed the same textual structure of these earlier statutes when it declared: "That no obscene ... book, pamphlet, [etc.] . . shall be carried in the mail, and any person who shail knowingly deposit [such things in the mail shall be guilty of a crime.]" 17 STAT. 598, 599 (1872). Compare the evolution of the lottery and fraud laws, where the first sanctions were plainly both civil and criminal. 17 STar. 322 (1872).

13. See Schroeder, “ObScEnNE” Literature and Constitutional LaW 65 (1911); Haight, BanNed Books 12 (1955).

14. For contemporary secondary source material reflecting the extent of customs and postal censorship and controversy over it prior to 1930, see, e.g., SCHROEDER, op. 
Some of these, of course, were "sport" decisions; all portrayed the extremities which could be reached when the law was loose. In 1929, Congress for the first time seriously discussed this sort of censorship and the concomitant dangers to freedom. A proposal to jettison the tariff prohibition calling for confiscation of "obscene" books was narrowly voted down, but the provisions for court review of customs seizures were tightened and a special exemption added giving the Secretary of the Treasury some discretion to permit non-commercial importation of obscene "classics and books of recognized and established literary or scientific merit." 15 And thereafter, federal courts interpreting the obscenity statutes-notably in the renowned Ulysses litigationrevised the legal "test" in an effort to curtail the censorial scope and impact of the law.

Smarting from the sting of the Ulysses opinions, the Bureau of Customs undertook a unique administrative experiment-the employment of an advisor to bring a sort of special, cultural expertise to bear on its determination of what constituted obscenity. The Post Office failed to follow suit, despite suggestions that it do so, yet a number of earlier, controversial bans on mail circulation were discarded. ${ }^{16}$

But during the early forties the Post Office mounted a new attack on magazines, and again the dangerous possibilities of overextended censorship were exposed. The power to revoke second class permitsimplied perhaps, but nowhere expressly authorized in any statutewas invoked against some seventy-odd offenders (including old barbershop staples like Police Gazette and Judge) apparently on grounds of their obscenity. ${ }^{17}$ This did not stop the burgeoning of that breed of

cit. supra note 13; HAIGHT, op. cit. supra note 13; DENNETT, Who's OBSCENE? (1930); ERNST \& SEAGLE, op. cit. supra note 4; Gilford, The Customs Men Keep Us Pure, 59 NEW REPUBLIC 176 (1929); Weeks, The Practice of Censorship, 145 ATLAN'IIC Monxhly 17, 21 (1930) ; 9 Cong. Dig. 50 (1930) (reprinting Senator Cutting's attack on Tariff Act enforcement).

15. Tariff Act of 1930, 46 STAT. 688, 19 U.S.C. $\$ 1305$ (a) (1952). The debates over its enactment covered the period October 1929-February 1930 and are scattered through volume 72 of the Congressional Record; See 72 Cong. REc. pts. 3, 4, 5, 6 (1929-30).

16. The Bureau's advisor is Mr. Huntington Cairns. For an account of his background and work with the Bureau, see CHAFEE, GoverNMENT AND MASS CommuniCATIONS c. 13 (1947). See also ATroRney GeNERAL's CoMIMITTEE on ADMINISTRATIVE Procedure, The Post OfFice Departarent 32-33, 95 (1940) (hereinafter cited as The Post Office Department) ; $i d$. Administration of the Customs Laws 116-22 (1940). For a discussion by Mr. Cairns of obscenity problems, see Cairns, Freedom of Expression in Literature, 200 ANNALs 76 (1938).

17. Material reflecting widespread use of the revocation sanction during the period 1940-1944 is to be found in files of the American Civil Liberties Union now located in the library of Princeton University; see, e.g., Vol. 2349, at 63, 77, 235; Vol. 2435, at 139; Vol. 2436, at 74. These materials contain correspondence between publishers, postal officials and ACLU staff members as well as press releases. See also the critical speeches of Senator Langer, 89 Cong. Rec. 3820-24, 4328-34 (1943), discussing this phase of postal censorship and listing titles of banned magazines. 
publication, and court decisions may have suggested doubts as to whether many were, in fact, "obscene" under the legal tests. But the Post Office attempted to enlarge the scope of its revocation power in order to deal with the danger of publishers who proffered such prurience. A second class mailing provision is a subsidy and should only be awarded as a "certificate" of publisher's "good moral character," wrote Postmaster General Walker in 1942. ${ }^{18}$ And shortly, the Post Office Department revoked the second class mailing privilege of Esquire magazine, claiming statutory authority to do so (and thus authority to cripple if not destroy its circulation) because the magazine was not for the "public good," even though it was conceded that its content was not "technically obscene." The Supreme Court, interpreting the statutory qualifications for second class rates, declared that the Post Office had acted illegally; the decision rejected the "hoary dogma" 19 that use of the mails is a privilege which Congress can regulate at will; it even cast some doubts about the power to revoke mailing privileges on grounds of past publication of obscenity. ${ }^{20}$ And, indeed, the Department abandoned, for the time being at least, use of that sanction to force compliance with its interpretation of the law.

The Esquire case and decisions like Parmelee v. United States ${ }^{21}$ and Walker v. Popenoe ${ }^{22}$ reflected considerable court recognition of the dangers of national censorship of vital channels of communication pursuant to standards which were vague, however well motivated. And indubitably, during the past decade the courts have liberalized the law. But there has been no solution of all problems.

So long as the law calls upon customs and postal officials to stop the circulation of any and all "obscene" publications, so long as courts define obscenity in imprecise terms of sexual stimulation or excessive indecency, so long as writers-good or bad-write about sexual experiences with realism and at the sacrifice of the modesty or euphemism of customary expression, so long as "cheesecake," or nude photography, or "spicy" magazines and even pornography are big business growing. bigger despite outraged outcries against their existence, so long as both the serious arts and those dedicated more to pure pleasure giving-depict sex in the way they do-so long as these conditions obtain there must be pressures and counter-pressures. The problem remains: How to frame laws, sound in substance, fair in procedure, which will protect

18. Postacaster General, Annual Report for 1942, at 12 (1943).

19. See Justice Harlan's opinion in Roth v. United States, 354 U.S. 76 (1957).

20. Hannegan v. Esquire, 327 U.S. 146 (1946). Compare Public Clearing House v. Coyne, 194 U.S. 497 (1904), with Ex parte Jackson, 96 U.S. 727 (1878).

21. 113 F.2d 729 (D.C. Cir. 1940).

22. 149 F.2d 511 (D.C. Cir. 1945). 
against "harms" assumed to exist and yet preserve freedom-freedom of expression, freedom to publish and circulate, freedom to read.

\section{Some Problems Reflected in Recent Experience}

At least since World War II, postal and customs "censors" have utilized two "tests" to determine whether a book or a picture is "obscene."

The first, derived from the Ulysses case, ${ }^{23}$ involves measuring the libidinous effect of the work on the reader. Will the work, judged as a whole and with regard to its artistic or educational purpose and merit, stimulate "lewd" thoughts or "sexual feelings" in the normal adult reader?

The second, derived from an early dictum of Learned Hand ${ }^{24}$ and decisions like Parmelee $v$. United States, has reference to the community's "standard" or "conscience" on what is tolerable and what is too outrageous depiction of sexual behavior or nudity in art or literature. In the phrase of Judge Hand, "the word obscene" is taken to "indicate the present critical point between shame and candor at which the community may have arrived here and now."

Space permits no examination, here, of procedures used to apply these criteria and enforce the postal and tariff laws. In essence, customs exercises a sort of primary jurisdiction over mail from abroad, impounding (for potential forfeiture proceedings in court) every importation which it detects and deems "obscene." ${ }^{25}$ The Post Office also exercises an impounding power over books and pictures found in the domestic mail-its "nonmailability" sanction. ${ }^{26}$ In addition, in appropriate cases, it is empowered to cut off incoming mail addressed to persons who are using the mails to advertise or sell works which the Department says are obscene-sometimes called the "mail block" sanctions. ${ }^{27}$

23. United States v. One Book Entitled Ulysses by James Joyce, 72 F.2d 705 (2d Cir. 1934).

24. United States v. Kennerley, 209 Fed. 119, 121 (S.D.N.Y. 1913).

25. Tariff Act of 1930, 46 STAT. 688, 19 U.S.C. $\$ 1305$ (a) (1952). In theory the statute simply authorizes the Bureau to seize suspected obscenity and produce it in court for an in rem, de novo proceeding looking towards forfeiture of the material. In practice, when the Bureau decides to seize, the importer is notified and asked to "assent" and "waive" court proceedings. This "notice" is quite brief and does not spell out the importer's right to a jury trial to contest the "seizure" with the burden on the Government. In most cases the "assent" is given. In some it is ignored, but even here, in the absence of a court contest by the importer, the forfeiture proceedings are a pure formality and the court never examines into the merits of the case.

26. 18 U.S.C. \$ 1461 (1952).

27. 25 STAT. 873 (1889), as amended, 39 U.S.C.A. $\$ \$ 259$ (b), (c) (Supp. 1956). See Summerfield v. Sunshine Book Co., 221 F.2d 42 (D.C. Cir. 1955), cert. denied, 349 U.S. 921 (1956), for discussion of constitutional problems raised when "mail blocks" are applied to cut off a publisher's mail service in toto, even though he is using the mails to disseminate lawful matter as well as an allegedly "obscene" work. 
By dint of court compulsion, the Post Office began, in 1951 to exercise its "mail block" sanction via procedures complying with the Administrative Procedure Act. ${ }^{28}$ In "nonmailability" cases, perhaps again by dint of conpulsion, a new statement of procedures has just been promulgated. It appears to bring "nonmailability" cases under the act. ${ }^{29}$ The Bureau of Customs makes no attempt to follow the act since in theory, by virtue of the terms of the Tariff Act, each of its decisions is reviewable de novo in the district court (though in practice very few seizures are contested or reviewed de novo at this level).

Even when and if formal postal hearings are held, there is uncertainty as to precisely what evidence is to be heard. Most of the cases decided under the Administrative Procedure Act thus far have involved pictorial matter. In determining whether the pictures evoke sexual desires or violate the community standard, the Post Office relies upon "inspection" of the challenged work by its "judges" (the hearing examiners) to yield the answer. The opinions of art experts or psychologists are seldom invited or admitted. For who is to judge their probative weight or value? ${ }^{30}$ Similarly, if a book suspected to be "obscene" is referred to Washington by a customs collector or postmaster for informal adjudication and a possible impounding order, the question of obscenity vel non is judged with little if any recourse either to outside expert testimony or to the circumstances involved in the actual case. The work is inspected and the officials decide, hypothetically, whether, if normal Americans were exposed, it would

28. Door v. Donaldson, 195 F.2d 764 (D.C. Cir. 1952). See Cutler, The Post Office Department and the Administrative Procedure Act, 47 Nw. U.L. Rev. 72 (1952). Cf. Walker v. Popenoe, 149 F.2d 511 (D.C. Cir. 1945). Prior to the Door case, the Post Office took the position that obscenity vel non was a question to be judged simply by "inspection" of the material, and thus that the determination was not subject to the Administrative Procedure Act, 60 STAT. 240, 5 U.S.C. $\$ 1005$ (1952). Considerable support for this proposition is to be found in the Acheson Committee's monograph. See The Post Office Departament 29-33.

29. For court action compelling this course see cases cited note 28 supra and note 74 infra. For the new rules on nonmailability cases, see 22 FED. REG. 8999-9000 (1957). In effect each "nonmailability" case is now initiated by filing a notice of the Assistant General Counsel's ruling with the Chief Hearing Examiner. This serves as a "complaint" which the mailer may contest via formal hearings. Recommended decisions by the hearing examiner on "periodical publications" must be made within forty-eight hours after the hearing. Note that these rules ignore the doctrine of Walker $v$. Popenoe discussed in text at note 73 infra.

30. This observation is based on interviews with the Chief Hearing Examiner of the Post Office and examination of case records in his files. See the Department's statement of its position in the Acheson Committee's monograph. THE POST OFFICE Department 95. Paradoxically, when the Post Office went after Irving Klaw, a vendor of various works depicting scantily clad girls wrestling, beating and torturing each other, it produced a psychiatrist at the hearing as part of its case to prove the works were "obscene." Ordinarily the Department does not, and says it is not required to offer such proof. Cf. Volanski v. United States, 247 F.2d 842 (6th Cir. 1957) (error to admit psychiatric evidence to prove obscenity where evidence is limited to showing "effect that pictures would have on sadists ... and other types of sexual deviates"). 
so titillate or shock them as to produce the assumed "harms" which the obscenity laws are designed to prevent.

Usually it matters naught that the actual recipient of the work might be a mature person with some particular interest in the work in question, who, in any event, is perfectly well equipped to regulate his own tastes in reading and control his psychic responses to sex expression. The present premise of obscenity laws-a heritage of the Victorian era-is that there are some books which no one should be allowed to see. This in the interest of protecting the public at large. Censorship acts today on precisely that premise, and, of course, far more efficiently than criminal law enforcement.

True, as an act of grace, the Post Office will sometimes make exceptions in an exceptional case-releasing an "obscene" work to a doctor or some other qualified recipient who particularly needs it for professional purposes. And pursuant to the Tariff Act, the Bureau of Customs can exercise discretion (nominally reposed in the Secretary of the Treasury) to release "classics" or books of "merit" when imported "non-commercially," but this dispensing power is conservatively construed and niggardly exercised. ${ }^{31}$

Several years ago the late Dr. Kinsey, in the course of one of his research projects, tried to import various samplings of erotica from abroad. Most of these importations could by no stretch come in under

31. "Provided firther, that the Secretary of Treasury may, in his discretion, admit the so-called classic or books of recognized and established literary or scientific merit, but may, in his discretion, admit such classics or books only when imported for non-commercial purposes." 62 STAT. 862 (1948), 19 U.S.C. $\$ 1305$ (a) (1952).

Importers are given no formal notice of their right to petition for discretionary release of seized material. There are no published regulations reflecting criteria used by the Bureau to decide (a) whether a book does enjoy the status of a "classic" or has "established and recognized literary or scientific merit," (b) whether a particular importer enjoys sufficient status to obtain release of the work. The Bureau construes the statute to mean that the "merit" of a work must be "recognized" and "established" in this country, though this construction hardly seems required by the text of the statute, let alone by the apparent legislative intent.

Examination of Bureau file material reflecting the handling of the various works of Dr. Edward Fuchs on the history of sexual morality reflects the difficulty of judging questions (a) and (b) above. On many occasions since 1931 various Americans have attempted to import these works which were published in Vienna and written in turgid German prose but which are well loaded with all sorts of illustrations, some extremely erotic, a "parade" of "obscenity" in the words of a former official. The file material shows that respectable opinion can be mustered for the premise once avowed by a Bureau official that "these books" are "decidedly of a shady [i.e., pseudo-scientific] character." Contrariwise, statements in the files by doctors, sociologists and librarians (including a former librarian of Congress) hold that the works are scholarly and the pictures highy relevant and useful to the text. At various times the Bureau seems to have barred the book altogether because of its lack of scientific status. The work has been confiscated from the household effects of several, obviously literate Viennese refugees entering this country; it has been taken away from many other importers who presented no scholarly credentials to the Bureau. On the other hand, it has been released, for example, to a psychiatrist, a law professor (whose field was domestic relations), a $\mathrm{Ph} . \mathrm{D}$. student of art history, and a lawyer whose only avowed interest in the work was that he was a book collector and an intellectual but who threatened showdown litigation if he didn't get what he wanted. 
the secretary's discretionary release power as presently construed. So the Bureau seized this material. Kinsey was barred, because an exception in his case would seem to require exceptions in others; difficult administrative problems might be encountered, and the whole concept of the law might have to be revised. Kinsey's successors have now carried his fight to the courts. ${ }^{32}$ The case poses a nice conundrum.

But if Kinsey's case is unique and extreme, others are not. American students of literature can't import the forbidden, unexpurgated works of D. H. Lawrence or Henry Miller, though these books, published in France and smuggled about pretty widely, have received a good deal of high praise from distinguished critics. ${ }^{33}$ No American, in theory, can have access, via the mail, to the autobiographical reveries of DeSade, let alone Frank Harris-though surely these works, too, may have some place in our culture if the volume of words written about them is any index.

Since 1940, applying the standards noted above, the Post Office has stopped mailings of the following books, among many others: From Here to Eternity; The Woman of Rome; For Whom the Bell Tolls; Strange Fruit; Appointment in Samarra; Diana; Memoirs of Casanova; Tobacco Road; God's Little Acre; The Second Sex and Mademoiselle Fifi. ${ }^{34}$ Each of these titles was involved in a case referred

32. See, e.g., 170 PUBLISHERS W WEKLY 786 (1956) for discussion of this case. Very recently the district court (S.D.N.Y.), announced its decision with an opinion as yet unreported, releasing the materials on the ground that, as to the recipients, there was no danger from release, and the materials should not be treated as obscene. We are advised informally that the Government wili appeal. Post Office rulings dated October 1, 1952 and April 28, 1952 reflect that the Department has released books otherwise deemed "obscene" to Dr. Kinsey solely because Dr. Kinsey was the recipient.

33. No attempt here is made to cite scholarly and other writings about Lawrence, Miller, Harris, De Sade and other authors of "banned" books. Henry Miller "presents an interesting case, however, because the Bureau also refuses to admit his "obscene" works under the secretary's discretion on the ground that they have no literary standing in this country. Our correspondence with the chairmen of the English Departments of Pennsylvania, Princeton, Harvard, Yale, Cornell, Columbia and Brown Universities and Dartmouth, Williams and Swarthmore Colleges on Miller's standing here as an author suggests at least some basis for the contrary conclusion. And see the bibliography of favorable comment on Miller by English speaking authors in PERLES, MY FRIEND HENRY MILLER (1956), including praise by Orwell, Eliott, Pound, Edmund Wilson and Aldous Huxley. Of course it must be emphasized that the courts have recently found Miller's books obscene. See, e.g., Besig v. United States, 208 F.2d 142 (9th Cir. 1953), which certainly confirms the Bureau's ban on importation (though not necessarily the ban on discretionary releases).

34. These rulings (except for From Here to Elernity and The Woman of Rome) are reflected in nonmailability rulings in the General Counsel's files dated, in order of mention in the text: Dec. 29, 1941; May 5, 1944; Sept. 24, 1941; Dec. 24, 1941; Apri1 8, 1941; March 25, 1941; Jan. 28, 1953; March 23, 1953; May 17, 1954. Information on From Here to Eternity and The Woman of Rome (which were banned in 1955) was supplied by counsel for the publishers. For spirited attack on rulings like these and on postal censorship in general, by a lawyer who successfully won reversal of a recent nonmailability order banning Aristophanes' Lysistrata, see DeGrazia, supra note 9, at 608 . 
by some postal employee in the field. In each a postal lawyer read the book and concluded that it was "obscene"-unfit for circulation via the mails, to the public.

It might be that today some of these rulings would be repudiated if new, contested cases arose, although the Department's files reflect the fact that they are still current. And of course it should be emphasized that, as a practical matter, the "ban" imposed in each of these cases was probably of negligible impact, for the law as interpreted in Washington depends upon consistent, widespread enforcement at the local level if it is really to be implemented. Since book rulings made in Washington are not circularized locally and since few postmasters-absent suspicious circumstances - have any desire to read and "censor" books offered for mailing and since postal lawyers themselves don't make any effort to implement such controversial rulings beyond the particular case involved, the dangers to freedom, if any, are more theoretical than real. Nevertheless, in theory, each ruling reflects the Department's conclusion that each of those books is unfit for adult Americans, that no seller should be allowed to advertise or sell it by mail and that no book club should attempt its distribution to members.

Postal policies on pictorial nudity-even when displayed in expensive art books-have posed problems. For example, a Philadelphia bookseller, specializing in the photographic arts, imported an expensive folio of nudes entitled Art International, containing pictures by the world's leading photographers. He offered it for sale via ads in reputable photography magazines. He was warned, with threats of "mail blocks" or worse by local officials, that the work might be obscene. When he protested to Washington, the Department confirmed: "This office has consistently held that photographic nudes are nonmailable," wrote the general counsel, and, again: "The photographic nudes in this book are indecent according to the moral standards of the nation." 35

The Philadelphia case typifies many others. Photos of nudes, good or bad, are regularly banned from the mails-unless sandwiched in very small numbers between the covers of an otherwise respectable publication. But even respectable publications can be censored. The magazine Scientific American was threatened with a ban until it removed from

35. The ruling is reflected in a nonmailability order dated April 16, 1955; additional information and correspondence relating to the case was furnished by the bookseller. The Post Office files reflect many similar rulings. On the other hand books featuring drawings and paintings of nudes seem generally to pass. But a woman who imported the privately printed Paintings of $D$. H. Lawrence in connection with her work on a biography of Lawrence was not allowed to receive it. Ruling dated May 16, 1951. Barrington's Anthropometry and Anatomy for Artists, though cleared by Customs was banned by the Post Office's ruling dated April 30, 1954. 
its cover a young, female native of New Guinea, clad above the waist only in flowers. ${ }^{36}$

The Bureau of Customs (which cleared Art International) is more liberal about nudity in photos. Whereas postal lawyers have insisted that virtually all photo art or cultist magazines featuring pictorial nudity are "obscene," the Bureau admits many such publications into the country. ${ }^{37}$ Tests for banning them seem to turn on suggestiveness of the pose, lack of retouching, etc. It is impossible to verbalize only formula; Bureau officials admit their vexation and disagreement with the Post Office and among themselves, in attempting to decide when an array of photographic nudity becomes contraband; one interviewed in San Francisco admitted they were "loose as a goose."

The Bureat also censors foreign movies brought into the United States for commercial distribution. The morality of a plot and theme is seldom questioned, and in many other respects the standards are most liberal (e.g., when judged either by the Hollywood "code" or by reported cases reflecting state and local-censorship experience). But in one respect a rigid line is drawn. The Bureau methodically requires expurgation of virtually all nakedness, no matter what the context or artistic merit of the scene. This on the theory that nudity, no matter how presented, violates an assumed community standard on what is acceptable undress in movies. The fact that different communities may have different standards, that nudity may or may not be artistically relevant-just as with its depiction in books-that it may be delicately handled rather than commercially exploited by exhibitors, and that commercial exhibition of movies can easily be locally policed seems to make very little difference. ${ }^{38}$ Again, the assumption is that circulation

36. Ruling dated December 3, 1953. Information was also furnished through correspondence with the publisher. The December 1953 issue of the same magazine was held up in New York because local officials questioned photos of nude male and female Amazon tribesmen; these photos were later cleared by Washington. Ruling dated December 11, 1953.

37. These observations are based on interviews and inspection of case files dealing with nudist materials as well as inspection of confiscated material. There is also evidence that Customs officials in the ports of entry will sometimes turn material over to the local post office to be judged by the stricter postal criteria. $C f$. Sunshine Book Co. v. Summerfield, 128 F. Supp. 564 (D.D.C. 1955); United States v. 4200 Copies Int'1 Journal, 134 F. Supp. 490 (E.D. Wash. 1956), wherein two different judges engaged in yeoman efforts to articulate the difference between obscene and non obscene photos of nudes; criteria having to do with the age and sex of the model, distance from the camera and disclosure of genital organs were adduced.

38. Nearly all commercially imported entertainment films come in through New York, and all are inspected. A short memo describing each film is prepared by the viewer, and objectionable material is described in more detail. The decision on seizure (either of the whole film or, more frequently, just short excerpts) is made de facto in New York although Bureau officials in Washington are advised by letter and memo of each proposed decision and formally authorize the proposals of the New York Deputy Collector. This "movie censorship" work is done in a very businesslike, fair way, making every allowance for the importers' desire for speedy action, and thus far 
of anything which meets the definition of "obscenity"-judging the thing by some hypothetical "typical" American audience-must be stopped.

The discussion above reflects some facets of the obscenity "censorship" problem. There are, however, other aspects which can't be ignored.

Commercial exploitation of pinup magazines, photos of nude women, "girl wrestlers," "stag movies," "bizarre erotica," paperbound fiction portraying and emphasizing sexual acts, sex sadism and lust, and other matter ejusdem generis, is a fact of life today. ${ }^{39}$ The mails are a major avenue of intercourse for this commercial traffic. A dealer in "stag" stuff needs little capital investment: a supply of wares to sell, a mailing list of prurient minded, potential customers (and these have been built up in the trade over the years) and perhaps a few ads in a "girlie" magazine (which shows how the "girlies," though largely banned from the mails, can and have become an integral element in mail order exploitation of salacity).

Since the dealer sends both his direct mail advertisements and his products in sealed letters, they cannot, as a practical matter be detected in transit. Moreover, most of these "operators" do business from the Los Angeles, Chicago and New York areas; experience indicates that unless they sell actual pornography or something pretty close to pornography, it is often hard to persuade jurors in those cities to convict them of a criminal violation of the Comstock Act. But postal censorship, while apparently not much of a deterrent, does stop a lot of this trade. Inspectors investigate suspicious enterprises by respond-

no importer has seen fit to challenge the Bureau in the courts. But cf. Excelsior Pictures Corp. v. Regents, 26 U.S.L. WEEK 2081 (N.Y. Ct. of Appeals Aug. 6, 1957) (holding that the nudist picture Garden of Eden, despite its nudity, was not "obscene" for censorship purposes. Cf. Times Film Corp. v. City of Chicago, 244 F.2d 432 (7th Cir. 1957) (upholding a total ban on the film Game of Love). This case was reversed by the Supreme Court without opinion but after inspection of the film. See note 1 sipra.

39. Discussion of this subject is based on, inter alia: interviews with the Chief of the Postal Inspection Service and various postal inspectors and other postal offcials; examination of material in the Hearing Examiner files; study of the various reported hearings of Senator Kefauver's Sub-Committee of the Judiciary Committee Investigating Juvenile Crime. See also NEW YoRk STATE JoINT LEGIsLative CoMMITTEE, Studuing Publications and Dissemination of OFFensive and OBscene MATERIAL (1957); id. (1956); id. (1955); id. (1954). Material in the possession of this committee was also revealing. See, e.g., Wagner, Parade of Pleasure (1955); Ellis, Folkiore of Sex (1951); Sorokin, The AMERICAN SEx REvoluTion (1956) for scholarly comment and description of this aspect of contemporary American life, each author representing a different approach toward the danger it presents. For an interesting history of the development of the so-called "sophisticated" (and more expensive) girlie magazines like Playboy, Tiger, Gent, Gem, Dude, Nugget and others see the long article captioned Racy Reading in Wall Street Journal, April 19, 1957, p. 1, col. 1. This discussion traces the phenomenally rapid growth in circulationentirely via newsstand sales (for they invariably are "nonmailable") 一of these magazines. For example, Playboy's circulation was reported at 900,000 . 
ing to ads, or getting on "sucker lists" through the use of fictitious names or by otherwise procuring samples of advertising and things sold. When appropriate proof is adduced, the Department starts "mail block" proceedings. Through default or by affidavit promising discontinuance or as a result of formal administrative adjudication, most offenders are put out of the challenged line of business. But new businesses pop up to supplant those defunct, to cater to the public's prurient tastes.

By flitting from enterprise to enterprise, Dorothy Tager-an unabashed female vendor of pictures of nude females, operating along the West Coast-parlayed an investment of a few thousand dollars into an annual gross running into millions. ${ }^{40}$ The notorious Irving Klaw grossed $\$ 1,500,000$ selling photos, drawings and movies featuring women beating or torturing women. Samuel Roth grossed thousands selling "strip sets," "wolf pacs," a publication called Good Times and many other items obviously designed to cater to salacity. ${ }^{41}$

Foreign dealers can, by the same technique, exploit American prurience. Paperback fiction-much of it quite pornographic-can be advertised and sold via the mails. The exporters themselves are beyond the reach of our criminal law. And, as a practical matter, criminal prosecution of importers is usually unwarranted or out of the question and thus no deterrent. ${ }^{42}$ Customs censorship is the only effective curb on the traffic. It apparently frustrates most foreign exploitation of the United States market, though precisely how effective it is, no one can say.

The above description of recent federal experience probably reflects, too, a good many of the problems confronting state and local law enforcement, for much of the "obscenity" which may flow into a community, may flow in via channels which are beyond local policing. And all this suggests that our obscenity laws pose something of a dilemma. On the one hand restrictions have been and are being put upon interests protected by our "first freedom," particularly the freedom of adults to decide for themselves what they are to read. On the other hand businessmen, for money making purposes, are exploiting commercially various species of "speech" which, when disseminated on a mass scale to audiences recklessly solicited via methods deliberately

40. Her unpublished but detailed "Autobiography," loaned to us by Mr. James Bobo, former counsel to the Kefauver Committee recounts the history of this business. This paper is in the committee's files.

41. See, e.g., 169 PublsHERS WEEKLY 241 (1956); id. 1035; 170 id. 617 (1956).

42. The Government must prove "knowing" importation. 18 U.S.C. $\S 1465$ (Supp. III, 1956). Customs officials in the ports studied do not remember ever referring any importation cases for possible prosecution. See note 1 supra. 
calculated to wet one's appetite for salacity, may work social harms to be avoided-although the precise effect which "bad" sex expression works on persons exposed to it is unknown.

Indeed, this void of knowledge magnifies the dilemma. For a search through "scientific" literature and the testimony of experts on witness stands apparently yields no consensus which will help answer questions of this sort: "John Doe is a mature adult; he wants to buy and read The Memoirs of Fanny Hill (that grossly pornographic tale obviously written to titillate, to cater to prurience-but a book which a university librarian recently labeled a "classic" when he asked the Bureau of Customs to release it). If John Doe reads Fanny's Memoirs, what harm will befall? Will John Doe become "corrupt," "promiscuous," "outraged" or upset from "psycho-sexual tension" (as various theories voiced at various times would suggest)? Does the fact that Fanny Hill is a sort of "classic" make it more or iess harmful? If Doe reads it will he suffer any more or less than if he reads something even more patently pornographic? Or Rabelais or Solomon's Song? Or if he contemplates pictures of undressed girls arrayed in a magazine? Or a movie? Or accounts of sex crimes splurged pruriently in a tabloid? Or DeSade?

There is, to repeat, no accepted answer to these questions. The writings of some psychiatrists suggest that if Doe, though an otherwise mature "adult," were "sexially immature," contemplation of such material-or some of it-might encourage him to indulge in "regressive" fantasies, and continued contemplation might tend to "arrest" his sexual development. Similarly, others suggest that it might stimulate some people, particularly adolescents, to masturbate which also may tend to arrest development. Others admit the masturbation point but deny harmful effect. Some psychiatrists insist that some peopleespecially adolescents-are seriously influenced by material depicting sexual "sadism" or "masochism" or "fetishism." Similarly with material depicting acts of physical cruelty. But the Kefauver Committee reports: "Majority opinion seems inclined to the view that it is unlikely that crime and horror comics would lead to delinquency in a well adjusted child." The most exhaustive "expert" study of the available, reputable psychological evidence concludes that there is no conclusion: We simply can't isolate the impact of one book as opposed to another, nor can we generalize about any class of books, nor about any of the various media to which we are exposed. The American Law Institute's Model Penal Code draftsmen surveyed the "scientific" literature and reported that "there is no psychiatric consensus." And again: "We know little or nothing about the consequences of reading 
obscene or shocking literature." Two legal scholars who have also surveyed the literature found no evidence "of a single effort at genuine research" to "test" any "assumption" about the "effect of sex literature upon sex conduct." The Kefauver Committee's report reflects the same uncertainty: Obscenity must be assumed to exert a bad influence, particularly on many juveniles, but evidence is admittedly lacking. And the United States, arguing in behalf of the validity of the Comstock Act, admitted the absence of evidence and was careful to avoid premises which assumed that there was proof of a particular cause and effect relationship. ${ }^{43}$

On the other hand, in view of the void of scientific knowledge, it seems unreasonable to be dogmatic either way on whether there is a need to exercise some control over obscene and pornographic expression. Many of the harms which have been singled out as the law's target may very well occur in some situations as a result of obscenity circulation. There may be undesirable and otherwise avoidable "psychosexual tension" or "promotion of lust" when obscenity is made freely available to all by business panderers-to adolescents, to sexually maladjusted people, to people who crave it. Some sort of triggering impact on the behavior of these people may more likely result, as some law enforcement officials have claimed. When sensitive people, against their consent, are exposed to filthy or erotic expression, some psychic harm may occur. When commercial exploiters of erotica are given free rein to sell whatever they choose to whomever they can entice to purchase by whatever means, then the law may have licensed dangerous activity. And also activity which few, at some degree, if any communities will tolerate.

What then is the best approach to the dilemma and particularly to the problem of the mails? Attention turns to recent contributions from the American Law Institute and the Supreme Court.

43. For psychiatric discussion, see, e.g., Testimony of Dr. Benjamin Karpman and Dr. George W. Henry before the Kefauver Committee, reprinted in NEW YoRk State Join't Legislative Commitref, Studying Publication of and DisseiminaTION OF OfFENSIVE aNd Obscene Matertals 59-66 (1956); Wertham, Seduction OF THE INNOCENT (1953); Abse, Psychodynamic Aspects of the Problem of the Definition of Obscenity, 20 LAW \& CoNTEMrP. Prob. 572 (1955); Eliasburg, Art: Immoral or Immortal, 45 J. CRIM. L., C. \& P.S. 274 (1954); Karpuran, ThE Sexual OfFENDER AND His OfFEenses 360 (1954). For the views of psychologists, see, e.g., Kinsey, SeXUal BeHavior in THe HuMan Female, 662 (1953) ; KINSEY, Sexual Behavior in the Human Male, 510 (1948); Jahoda, The Impact of LiTERATURE 15-16, 22-23, 30-33, 44 (1954). Dr. Jahoda vigorously attacks Dr. Wertham's thesis that "comic books" "cause" delinquency. See also the unpublished summary by Dr. Jahoda of her views which appear verbatim in Judge Frank's opinion in United States v. Roth, 237 F.2d 798, 815-16 (2d Cir. 1956). See also for general discussion on the impact of reading, WAPLES, BERELSON \& BRADSHAW, WHAT READING DOES TO PEOPLE (1940). For the views of the Kefauver Committee to the effect that no definite conclusion can be drawn on the causal relationships between mass media and juvenile crime, see S. Rip. No. 62, 84th Cong., 1st Sess. 12 (1956); S. REP. No. 130 , 


\section{The Model Penal Code's Approach}

Last Spring the American Law Institute brought forth its tentative Model Penal Code proposals on obscenity. The quest was for a rational statute, and one which would 'reflect changes in men's views of the importance of freedom of expression. . . ." 44 Comments explaining it re-evaluate the function of such laws, and the code itself offers a new definition of obscenity.

Perhaps the underlying premise of the ALI proposal is reflected in these excerpts: "Psychiatrists and anthropologists see the ordinary person in our society as caught between normal sex drives and curiosity, on the one hand, and powerful social and legal prohibitions against overt sexual behavior. The principal objective of [the statute] is to prevent commercial exploitation of this psychosexual tension." [Emphasis added.] And again: "Society may legitimately seek to deter the deliberate stimulation and exploitation of emotional tensions arising from the conflict between social convention and individual's sex drive." Thus: "The gist of the offense we envisage, therefore, is a kind of [commercial] 'pandering.' " 45

Consistent with this end the code re-defines "obscenity": "A thing is obscene if, considered as a whole, its predominant appeal is to prurient interest, i.e., a shameful or morbid interest in nudity, sex, or excretion, and if it goes substantially beyond customary limits of candor in description or representation of such matters." 46

Since the law's paramount objective, as avowed by the code's draftsmen, should be to stop commercial "pandering," the code might have limited its prohibition to precisely that kind of dissemination of "obscenity" (as the term is redefined), plus perhaps a ban against all (except, perhaps, parental or educational) dissemination to adolescents. This course would have the merit of curbing the more demonstrable dangers which obscenity circulation may produce, while still preserving a maximum freedom for mature adults to regulate their own reading

85 th Cong., 1st Sess. 127 (1957). For the views of laymen who have studied the literature on the subject, for the purpose of evaluating premises advanced to justify suppression of books, see, e.g., Alpert, Judicial Censorship of Obscene Literature, 52 Harv. L. Rev. 40 (1938); ALI, Model Penal Code Tentattve Draft No. 6, at 22-27, 32 (1957); Lockhart \& McClure, Literature, The Law of Obscenity and the Constitution, 38 Mins. L. REv. 295 (1954); MCKEON, MERTON \& GELLHORN, FreEdom To READ 72-75 (1957). See also Brief for the Appellees, p. 54, Roth v. United States, 354 U.S. 474 (1957). The opinion of many law enforcement officers to the effect that there is a nexus between juvenile crime and "obscene" publications are set forth throughout the various published hearings of the Kefauver Committee and the reports for 1953, 1954, 1955, 1956, and 1957 of the New York State Joint Legislative Committee, stlpra.

44. See Ali, Modee Penal Code Tentative Draft No. 6, at 5-9 (1957).

45. Id. $10,14$.

46. Id. § $207.10(2)$. 
as well as a broader freedom for writers, publishers and booksellers. This course was considered but rejected on the gounds that it was impossible to define a "pandering" offense.

Instead, the code proscribes all dissemination except: (1) "dissemination not for gain" among adult "personal associates," (2) dissemination "not for gain" among juveniles, and (3) dissemination to "institutions" and "persons" having "scientific" or other "special justification" for receiving. ${ }^{47}$ There is also a novel mens rea to the offense: the defendant must circulate with knowledge of the "obscene" character of the work or with "recklessness" in that regard; though there is a presumption in favor of this mens rea upon proof of other elements, it can be rebutted by evidence of honest mistake in judgment or ignorance. Thus, indirectly, the mens rea elements tends to confine criminal liability to the "pandering" type offense which is the code's target. ${ }^{48}$

These proposals surely make valuable contributions by rational appraisal and identification of the "harms" which the law should seek to prevent, by offering a new definition of obscenity (the merit of which is described below,${ }^{49}$ by inclusion of a mens rea defense, and especially by expressly creating privileged, dissemination transactions. Of course, as a practical matter penal law has seldom concerned itself with the transactions which the code now expressly exempts. But federal censorship has (e.g., notably in Kinsey's case), and introduction of these ALI criteria into postal and customs interpretation of the law would, no doubt, promote the interests of freedom.

There remains the problem, however, whether, at least as far as censorship is concerned, these changes go far enough.

47. Id. $\$ 207.10(4) ; i d .14-15$.

48. Id. 49-52.

49. The following excerpts from the code's comments may serve to point up the purpose and contribution of the proposed new test. "The commonst [sic] definition of obscenity in the cases is in terms of tendency of the material to arouse sexual thoughts and desires or to corrupt the morals, meaning in this connection the sexual morals, of the reader or viewer." Id. 19. "As an independent goal of penal legislation, repression of sexual thoughts and desires is hard to support. Thoughts and desires not manifested in overt antisocial behavior are generally regarded as the exclusive concern of the individual and his spiritual advisors." Id. 20. "We reject the prevailing test of tendency to arouse lustful thoughts or desires because it is unrealistically broad for a society that plainly tolerates a great deal of erotic interest in literature, advertising, and art, and because regulation of thought or desire, unconnected with overt misbehavior, raises the most acute constitutional as well as practical difficulties." Id. 10 . "The proposed [Model Penal Code] definition of obscenity has three elements: (i) the material must appeal to prurient interest in sexual matters; (ii) that aspect of its appeal must predominate over other attractions or values in the material; and (iii) the appeal to prurient interest must be by description or representation going substantially beyond customary limits on free expression. Although obscenity has rarely, if ever, been defined as we propose in terms of appeal of the material rather than its tendency, the terms we employ are not novel, and the idea often appears in discussion of what is obscene." Id. 29. 


\section{RECENT JUdicial INTERPRETATIONS}

In the early spring of 1957 a unanimous Supreme Court wrought the demise of Hicklin oriented obscenity standards. The Court invalidated a Michigan statute which incorporated Cockburn's "test" almost in terms. ${ }^{\text {00 }}$ It then proceeded to set down three additional cases for argument: a Comstock Act prosecution, a California prosecution under a typical state anti-obscenity criminal statute, and a prosecution under a New York statute authorizing courts to enjoin future sale of books found "obscene." In each case the statute offered no definition of the term "obscene"; in each the sole issue to be reviewed was the validity of the law on its face..$^{51}$

The federal prosecution involved the notorious Sam Roth. Over the protest of the late Judge Jerome Frank, the court of appeals affirmed his conviction of peddling a book called American Aphrodite. ${ }^{52}$ The trial judge had given a Ulysses type instruction-does the work "considered as a whole," have a "tendency to excite lustful thoughts" in the mind of "an average person"? And also a "community standard" instruction-"you judge [the work] . . . by present day standards. . Does it offend the common conscience of the community"? ${ }^{53}$

Judge Frank wrote, in essence: ${ }^{54}$ We are midpoint in the twentieth century, and it is high time for reappraisal of the anti-obscenity laws in the light of experience, science and today's legal conception of the right of free speech. I doubt the constitutionality of the Comstock Act. Obscenity dissemination, a ridiculously vague crime, punishes people for selling books or pictures which may only evoke "lustful thoughts" and nothing more. This is carrying governmental suppression too far.

Reviewing what scientific evidence he could muster, Judge Frank urged that there was no demonstrable nexus between lustful thoughts and resultant misbehavior-no proof that obscene books produce misconduct. In the absence of this proof, said he, the law should make no attempt to suppress the expression. Noxious it may often be, but experience with the persecution of good books once thought to be bad should sober the urge to rid the community of all we now label as

50. Butler v. Michigan, 352 U.S. 380 (1957).

51. Alberts v. California, 352 U.S. 962 (1957) ; Kingsley Books, Inc. v. Brown, 352 U.S. 962 (1957); Roth v. United States, 352 U.S. 964 (1957).

52. 237 F.2d 796 (2d Cir. 1956).

53. Record, p. 25, Roth v. United States, 354 U.S. 476 (1957).

54. While labeled a concurrence, Judge Frank's opinion was in essence a dissent based on his "difficulty in reconciling the validity of [the postal statute] . . . with opinions of the Supreme Court uttered within the past twenty-five years, relative to the First Amendment as applied to other kinds of legislation." And see his similar opinion in Roth v. Goldman, 172 F.2d 788, 790 (2d Cir. 1948). For an attack on the philoşophy of Judge Frank's opinion, see Schmidt, A Justification of Statutes Barring Pornography From the Mail, 26 FordhaM L. REv. 70 (1957). 
lascivious trash. For some "obscene" creations may have some enduring merit. Let all alone as the price of freedom-unless and until we can identify that obscenity which not only seems worthless, but which also presents some tangible danger of resultant crime or delinquency-more clear and more present than mere stimulation.

A divided Supreme Court disagreed with this analysis and sustained each statute. ${ }^{\overline{5}}$ Justice Brennan wrote for the majority in Roth's case. Obscenity, he noted, could be variously defined. In his opinion the new, untried ALI definition (identifying obscenity as that which "predominantly appeals to prurient interest") focuses on the essence of its badness-the fact that its predominant appeal is to "morbid" or "lascivious" longings. But, said he, laying down a proposition which seems patently inconsistent with the expressed philosophy of the Model Code proposal, ${ }^{56}$ the "appeal to prurience" formulation was only another way of stating the old, traditional tests, the definitions utilized by the trial court in Roth's trial (i.e., "tendency to excite lustful thoughts" or "offensive to the community's conscience"). Any or all of these formulations of the "test" seemed acceptable to the Supreme Court. Arguments on unconstitutional vagueness were swept aside, summarily.

Having thus defined obscenity, the Court's five man majority proceeded to endorse the proposition that all publications meeting these criteria are useless to mankind and warrant no protection under the first amendment. Obscenity, said Justice Brennan, is "utterly without redeeming social importance." So whether its circulation creates a "clear and present danger" or no real danger at all is irrelevant. Like libel, obscenity can be suppressed without proof of its impact on behavior.

Just as the Court summarily disposed of the vagueness and clear and present danger arguments, so it disposed of a third. Amicus Morris Ernst, ${ }^{57}$ longtime opponent of sex censorship, strongly argued that a combined reading of the first, ninth and tenth amendments shows there is no federal power to regulate the content of "speech" for the purpose of protecting morality. Again the answer was: "obscenity" is "not expression protected by the first amendment."

55. Roth v. United States, 354 U.S. 476 (1957) ; Alberts v. California, 354 U.S. 476 (1957); Kingsley Books, Inc. v. Brown, 354 U.S. 436 (1957). The Roth and Alberts decisions were treated together in single opinions by both Justice Brennan and the dissenting and concurring Justices.

56. See note 49 supra.

57. Mr. Ernst enjoyed the distinction of being permitted to file a brief in his own behalf and in his own name. It is devoted principally to the argument noted above. This point was also raised for petitioner Roth by his own counsel. 
The same basic premises underlay Kingsley Books, Inc. v. Brown, ${ }^{68}$ which sustained the New York statute authorizing court injunctions. Justice Frankfurter, for the majority, wrote: "If New York chooses to subject persons who disseminate obscene 'literature' to criminal prosecution and also to deal with such books as deodands of old, or both, with due regard, of course, to appropriate opportunities for the trial of the underlying issue, it is not for us to gainsay its selection of remedies."

All of this did not sit so well with some Justices. As Justice Harlan noted: "The Court seems to assume that obscenity is a peculiar genus of 'speech and press' which is as distinct, recognizable and classifiable as poison ivy. . . . I cannot agree that any book which tends to stir sexual impulses [etc.] . . . is utterly without redeeming social importance." And surely experience, at least with application of the now approved obscenity standards in federal censorship cases, supports the conclusion.

Embracing the late Justice Jackson's view of the interrelationship of the first and fourteenth amendments, Justice Harlan concluded that the constitutional limitations on state power to deal with obscenity, as opposed to those on federal power, were quite different. State proscriptions were to be judged by their reasonableness, but there is no federal power to regulate the content of sex expression in the interest of protecting morality.

Chief Justice Warren, concurring in the result in Roth and dissenting in Kingsley, insisted that blanket proscriptions against all dissemination of obscenity were invalid. In essence he would uphold suppression by criminal prosecution and perhaps by prior restraint (though that is not clear) only when the disseminator engages in conduct amounting to "pandering" and commercial exploitation of the obscenity.

Devout in their belief that the words "no law" in the first amendment mean "no law"-no law which punishes speech independently of its demonstrable harmful effect-Justices Black and Douglas seemed to insist that the "clear and present danger test" must be met before publishers could be jailed because of the content of their work.

Justice Brennan, in a somewhat surprising shift, dissented in Kingsley. The vice of New York's "prior restraint," as he saw it, was its failure to guarantee a jury trial on the issue of obscenity. Only with this "safeguard" could there be assurance of "competent application" of the "obscenity standard" (pursuant to the criteria endorsed in Roth's case). 
Justice Brennan's jury trial, constitutional caveat in the Kingsley case suggests interesting questions about future obscenity litigation in the Supreme Court. Who on the present Court will vote to sustain what kind of a law? Suppose, for example, the constitutionality of postal censorship was precisely the issue; not criminal enforcement of the Comstock Act, but administrative enforcement via "mail blocks" or "non-mailability" orders?

Two Justices (Black and Douglas) seem to say there can be no suppression of any sex expression-even when we characterize it as "obscene"-without evidence of a "clear and present danger" of harm from its publication. One Justice (Harlan) seems to say: no federal power: the states can use criminal or civil sanctions, but the federal government cannot. One Justice (Brennan) seems to say: jury trials are a sine qua non to assure fair enforcement of the law (and, of course, postal censorship supplies none). A fifth member of the Court, the Chief Justice, who dissented in Kingsley, says: "It is the manner of use that should determine obscenity. It is the conduct of the individual that should be judged, not the quality of the art or literature. To do otherwise is to . . . violate the [first amendment]. . . " But the standard here espoused is by no means the standard reflected in postal censorship. On the contrary, books, magazines and pictures have been banned from the mails regardless of the "manner of use" or the "conduct" of the publisher.

Thus, it is very possible that the announced views of five members of the Court, divergent as they may be, suggest the conclusion that postal censorship, as now practiced, is unconstitutional.

But analysis of the problem should not stop there. Other factors suggest the need for modification of the Court's approach to the obscenity problem-at least when it comes to examination of constitutional limitations on censorship restraints.

In the first place (and recognizing that labels should not be used as "self wielding swords" 59 in analysis of first amendment problems), there is the fact that censorship is a "prior restraint." It is practiced outside the courts. Policies and criteria are fixed and applied by relatively few officials, operating in Washington, removed from the variances of local community tolerance and attitudes, removed from direct accountability to juries. Their decisions, in theory, (more so than in practical effect), can be of quite sweeping importance, e.g., no one can circulate Hecate County via the mails, and this even though United States attorneys may and have declined to prosecute booksellers who do.

59. See Justice Frankfurter's opinion, Kingsley Books, Inc. v. Brown, 354 U.S. 436, 441 (1957). 
Criminal enforcement of the Comstock Act has a more limited impact. Conviction of one individual in one case for selling a book does not necessarily bar another from selling the same work elsewhere, or even in the same locale. Further, because criminal law administration is less streamlined and more inefficient than censorship-hedged in as it is by all the traditional protections accorded the accused and all the practical obstacles which frustrate prosecutors-criminal law enforcement is less likely to result in suppression of more innocuous publications, less likely to interfere with limited, discreet circulations of a work which censors might well find "obscene" and thus ban in toto.

These practical facts of law administration can make a great difference in net results. And, confining our attention to federal antiobscenity enforcement, it is clear that they have. Criminal enforcement usually operates, today, with much less impact, much more selectively against the more flagrant commercial disseminators and those who purvey outright pornography. ${ }^{60}$

In the second place, it seems apparent that the Court's prevailing opinion about what is obscenity and when and why it may be suppressed, requires some further analysis and qualification.

Sweeping assumptions were invoked by Justice Brennan and his four colleagues to support their conclusion that Congress has the power to put people like Sam Roth in jail. Eschewing appraisal of existing experience, the Court in effect said: (1) "obscene" publications can be identified and distinguished from legitimate art and sex expression without much risk of much mistake; (2) "obscene" publications (as identified by applying the standards) have no social value whatsoever.

Passing the question whether these assumptions are accurate in light of what we may know about federal criminal anti-obscenity en-

60. In the course of field studies connected with our study, United States attorneys who handled obscenity prosecutions in New York, Chicago, Los Angeles, Philadelphia and San Francisco were interviewed. As far as large scale commercial operations in obscenity are concerned, the first three cities are the most important because most major mail operators work from these locales. While it is impossible to generalize broadly, an investigation of major cases involving commercial dissemination brought in these districts indicates some variance between what prospectors think jurors will think is obscene and what postal officials think is obscene. A disseminator of pictorial matter featuring female nudity, if detected, will almost invariably run afoul of the civil sanctions. But criteria for prosecuting him suggest that something more than mere nudity is required, e.g., lack of retouching, highly suggestive poses and widespread commercial distribution. In the Roth case the jury acquitted Roth for mailing nudes though the prosecutor made a special plea that they fix "a standard" that would outlaw such pictures. The Post Office's non-mailability files reflect instances where the United States attorney has declined prosecution of a shipper of books (e.g.s a case involving a book containing excerpts of De Sade's works, a case involving God's Little Acre) which the Department thought were obscene. Perhaps close to $50 \%$ of the criminal prosecutions under the Comstock Act involve more or less "private" mailings of homemade pornography or filthy, scurrilous letters. 
'forcement, it seems plain they just do not ring true as characterizations of experience under censorship.

The Post Office and the Bureau of Customs cannot agree about pictorial nudity-how much is too much for the good of the public. They seem to disagree on some fictional works. The Post Office censors some magazines which apparently sell openly in respectable newsstores in respectable communities. The Bureau of Customs insists that virtually all depiction of nudity in foreign films be blotted out-this on the assumption that there is some uniform condemnation of nudity that offends every "community's conscience." Both agencies have banned some books which many Americans think are worth the time of mature adult readers.

Who is wise enough to say that Lady Chatterly, the forbidden works of Ovid, Miller, De Sade and Frank Harris, Hecate County, God's Little Acre, From Here to Eternity, The Woman of Rome, or Mark Twain's 1601, and many others which have been proscribed, are "utterly without redeeming social importance"? Who is confident that he can demonstrate that some or all of these books are or are not "obscene" under the existing standards which purport to tell us what obscenity is? ${ }^{61}$ The Library of Congress carefully preserves copies of books seized by the Bureau and even makes many available to the general public. And if the law is to operate on the assumption that all "obscene" works are fit for oblivion, why did Congress, legislating in 1930, speak of "obscene" "classics" and "obscene" books of "recognized literary merit"?

The portrayal of "sex," admitted Justice Brennan, "has undisputably been a subject of absorbing interest to mankind through the ages"; freedom to discuss or portray it is guaranteed as an element of freedom of speech, and the courts must practice "ceaseless vigilance" to assure that freedom. But there the thought was left dangling, and the exhortation, too. For we are also told that if you portray sex in a manner which others will evaluate as an "appeal to prurience" or incitement of "impure sexual thoughts" or an offense to the "community's conscience," then you have created something automatically worse than worthless. As if these collections of words ("inciting impure sexual thoughts," etc.) were self-executing formulae, handed down from

61. The case of Hecate County is a good example. The Post Office apparently bans it. The Bureau of Customs, reversing itself (when an importer represented by counsel threatened litigation), cleared it in 1954. The Supreme Court split four to four (with Justice Frankfurter out) reviewing a New York prosecution which challenged the validity of a state court decision finding that the work was obscene. Doubleday v. New York, 335 U.S. 848 (1948). The book was recently cleared by a California judge in criminal prosecution (according to information in the Bureau's case file on the book). 
Sinai as the supreme test of the existence of something worthy of any mature man's contemplation.

\section{A Suggested Approach to Postal Censorship: Substantive Standards}

Space precludes more detailed discussion here of the constitutionality of federal restraints. Despite possible criticisms of the result in Roth, or some of its reasoning, the fact remains that the Court has upheld criminal restraints. There may still be quite serious doubts about the validity of censorship as now practiced. Yet it may be fair to assume, in light of Kingsley, that if the operation were changed so as to meet, at least in part, objections voiced by Chief Justice Warren, Justice Brennan or Justice Harlan (or all of them), the Court might well find a majority to sustain it.

Moreover, it is probably only realistic to assume that for the time being the public and Congress will demand that the Post Office continue to exercise civil sanctions to keep obscenity out of the mails. Revelations reflecting the scope of mail order businesses in erotica, the growth of the "girlie" magazine business and other serious aspects of the problem may be invoked to point up the need for continued civil as well as criminal sanctions, particularly in view of the difficulty which prosecutors say exists in securing jury verdicts in the areas where so many distributors do business. It is most important to remember that many of these "publishers" are motivated by profits; many, like Sam Roth, will apparently skirt the threat of jail just as close as they can, in the course of efforts to stimulate prurient interest and thus sales in the salacity which they offer. It is important to remember, too, that local law enforcement is virtually powerless to police out of state businesses which use the mails or the channels of foreign commerce.

In any event, for present purposes we put aside personal predilection on the question, is it desirable to continue mail censorship? Assuming (1) that Congress can, constitutionally, provide for civil restraints and (2) that it will wish to do so, there remains the problem of limiting censorship to the imposition of curbs on only the more demonstrable dangers produced by obscenity in the mails.

The trouble with most obscenity laws today is that they operate on the premise that once something can be classed as "obscene" then nobody should see it. Not even adult, educated citizens.

The dichotomy which holds that a work is either fit or unfit, has been foisted on us by the historical development of the law. It is 
this premise-particularly when enforced via federal censorship-which makes controversial decisions a matter for real controversy. There would be less concern over a decision that a given work was "obscene," if the law stopped acting on the assumption that all dissemination must cease once the epithet is fastened on the work.

In view of men's ignorance, prejudices and oft demonstrated fallibility in this field, why not strike a compromise? Cease the attempt to forbid all circulation of obscenity. Forbid circulation only when the transaction-the manner of circulation-involves conduct which more justifiably permits governmental interference.

Thus, we would start by accepting the definition of "obscenity" now promulgated by the Supreme Court (although it is to be hoped that there will be future recognition of the fact that the ALI "test," now apparently amalgamated into federal law, is not just a reformulation of old standards but rather a new test with a different emphasis). ${ }^{62}$ For in view of the Supreme Court's decision, and in view of the difficulties with other proposals (for example, definitions couched in psychiatric terms, or in terms of the clear and present danger test), ${ }^{63}$ it is probably unrealistic to plump for any drastic reformulation of the definition. So let us assume that the term "obscene" indicates a work which, judged "as a whole," violates the community standards, produces sexual desires and predominantly appeals only to prurient interest.

With obscenity as only one element of the case, a second, equally indispensable, should relate to conduct: the "manner of use," as Chief Justice Warren put it. The problem is whether we can identify, with sufficient precision, alternative kinds of dissemination which justify suppression.

Tentatively at this point-with recognition of at least some of the troubles involved-the following classification is offered:

(1) Knowing circulation of obscenity to adolescents. This conduct should be prohibited in the interest of according protection to the immature and protection to parental prerogatives and rights. It is one thing to assume (or operate on the risk) that adults should have freedom to choose the books they shall read, and another to insist that children shall have the same freedom. It may be more reasonable to assume more likelihood of harm to the individual here, even though the

62. See note 4 supra. See also the comments of the draftsman to this effect, Schwartz, Criminal Obscenity Laze: Portents From Recent Supreme Court Decisions and Proposals of the Anerican Law Institute in the Model Penal Code, 29 PA. B.A.Q. 8 (1957).

63. See, e.g., Eliasburg, supra note 43; Commonwealth v. Gordon, $66 \mathrm{~Pa}$ D. \& C. 101 (Q.S. 1949). 
scientific proof is lacking; certainly the public is not prepared to accept the risk. The spectre of a purveyor of pornography peddling outside a school house without restraint is an extreme example of conduct intolerable to most parents, and the purveyor who seeks out youth via the mails is only a step removed-more in space than degree. At the same time, the law should not attempt outright prohibition of all distribution when there may only be a possibility that adolescents will be reached (e.g., as in the case of a magazine publisher whose product may reach youngsters for all he knows). This would be imposing a burden on publishers equivalent to maintaining the law in its status quo. Commercial vendors certainly should be restrained from selling recklessly to an unseen audience, but that should be accomplished by a second, alternative standard of proscribed conduct.

(2) Commercial exploitation of obscenity. Contrary to the ALI, we would permit, as far as censorship is concerned, booksellers and publishers to use the domestic mails to sell works which, when judged in the abstract, might fit the definition of obscenity. At the same time, we would recognize the necessity for restraints on this kind of distribution. Left subject to no control, businessmen can-they do nowdeliberately use obscenity in a way which increases the likelihood that its distribution will work harms to be prevented-e.g., circulation to adolescents, exploitation of "psycho-sexual tensions," reckless distribution of erotica for use as "aphrodisiacs." This business conduct should be curbed. The trouble here is probably less with the desirability of the objective than with defining and delimiting conduct constituting "exploitation." Recognizing that difficulty, we believe that at least as far as restraints on commercial mail distribution are involved, it may be possible to draw a reasonable line; at least there should be exploration of the possibility.

(3) "Assaulting" people with obscenity. The prohibition here relates to deliberate exposure of people to obscene expression against their consent, without justification and under circumstances which involve a likelihood of mental disturbance-serious affront, shame, fear or disgust. For example, consider the crank (who may be far from harmless) who sends a mash letter or postcard or other communication which is scurrilous and filthy to a sensitive woman-this kind of conduct, while perhaps often the product of mental disorder and seldom a matter appropriate for censorship, should be prohibited so that it can be policed. ${ }^{64}$

64. Perhaps a controversial example of this problem is United States v. Gundelfinger, 119 F.2d 1023 (3d Cir.), cert. denied, 314 U.S. 617 (1941) (conviction for vio- 
The first and third categories above may present less difficulty than the second. But the second deals with commercial vending-the big problem today, and the situation most usually encountered in censorship enforcement. What more precisely constitutes "exploitation," in the sense of prohibited commercial vending?

The conduct proscribed should be defined in terms of the harms to be avoided.

As noted, we see minimal danger in discreet distribution of obscene works to mature persons. At least insofar as the processes of national censorship are concerned, that is a risk which should be borne today. But when the vendor deliberately stimulates and creates a market for obscenity by utilizing the obsceneness of his wares as a means to promote their sale, then the case changes. Again, when the commercial seller uses the mails to engage in widespread, indiscriminate selling to an unknown audience, he is creating a ready and more easily accessible market for precisely those elements of the population who may be adversely affected, and his conduct becomes dangerous and more so depending upon the degree to which the materials are obscene. (And let us recognize that there are certainly degrees of "obsceneness.") So the conduct element of the standard tentatively advanced here would have the commercial disseminator of an obscene work use due care to refrain from any course of commercial conduct which incurs these risks. ${ }^{65}$

But to pose a more concrete and recurring problem which may reflect the difficulty of drawing lines here: When does a disseminator of a nudist or pin-up magazine or an erotic book become a "commercial exploiter" of obscenity? Assuming that the work is "obscene" under

lating the Comstock Act affirmed). The history of this case may only be obtained by reading the record, since no court to adjudicate it deigned to write an opinion. Gundelfinger, a former teacher at Yale, wrote tracts which he mailed widely, at his own expense, unsolicited, to Yale students and alumni. These tracts advocated the value from both a physical and psychic standpoint of practicing, specifically at Yale, a form of masturbation. Gundelfinger urged Yale students (including the football team) in long-winded, scientific or pseudo-scientific terms to join his "crusade." Whether his works really were obscene (either as erotic writing or "filthy" writing) may be a close question. But assiming they were patently obscene, one might question whether he should have the right to send such pamphlets to Yale students, alumni and other persons without their permission. Our proposal would prohibit it.

65. Cf. $\S 207.10(6)$ of the Model Penal Code which punishes a "person who advertises or otherwise promotes the sale of material represented or held out by him to be obscene." The conduct prohibited is described in the comment as "playing on prurient interest, holding out the promise of forbidden thrills." In this connection it is interesting to scan some of the full page, illustrated mail order advertisements for Boccacio's Decameron appearing in many of the "girlie" magazines. C $f$. United States v. Hornick, 229 F.2d 120 (3d Cir. 1956). See also In re Cadillac Publishing Co., Hearing Examiner Docket No. 1/244 (1955) for a Post Office ruling imposing a "mail block" on the Cadillac Publishing Co. on the ground that its mail-order advertising of its Encyclopedia of Sex, while not obscene, was represented as obscene. The General Counsel's decision was recently sustained by the District of Columbia District Court (Holtzoff, J.). See 26 U.S.L. WEEK 2186 (Oct. 15, 1957). 
the tests (as must be the case before we need concern ourselves with the conduct of the distributor), the question of whether this presents a case for federal control would still have to turn on analysis of the cumulative weight of several variables: (a) the degree to which the materials transcend the law's standard; (b) the extent to which the disseminator's advertising methods were calculated by appearance, content and audience solicited to stimulate prurient interest and desire for the materials; (c) the volume of his distribution of the obscene work; the volume of his advertising and attempted circulation of it; (d) the extent to which he has distributed to an unknown audience which, under the circumstances, may well be made up of adolescents or susceptible persons; (e) his apparent purpose in engaging in this distribution of obscenity as reflected by his course of conduct-has the publisher been indifferent to the risks involved in the circulation in which he knowingly engaged?

These factors are suggested as separate criteria, each to be weighed for its worth, in judging whether conduct constitutes "exploitation." And, it should be re-emphasized that the obscenity must be found before the question of "commercial exploitation" arises. Thus the standard suggested is less restrictive than any now in force. Of course the conduct element is broad and therefore vague. But, for censorship purposes at least, this new element of vagueness should hardly increase the danger of undesirable curbs on publishing, bookselling and reading. Further, the proposal must be judged relatively, in light of available alternatives.

These proposals (to be explored in more detail in our study) may be difficult to spell out, initially, but they are surely not novel. The Model Penal Code, while it does not go quite as far with its proposed criminal standards as we would in the civil field, plainly seeks to predicate liability on bad behavior-not just the violation of an abstract standard. Some time ago, Judge Learned Hand struck a similar theme in a criminal case involving a mail order peddler ${ }^{66}$ and so did a panel of the court of appeals in Washington, quite recently, when it reviewed a non-mailability order imposed against a nudist magazine. ${ }^{67}$ And so of course did Chief Justice Warren in Roth and Kingsley. ${ }^{68}$

66. United States v. Rebuhn, 109 F.2d 512 (2d Cir. 1940). Cf. United States v. Levine, 83 F.2d 156 (2d Cir. 1939).

67. Sunshine Book Co. v. Summerfield, 24 U.S.L. WEEK 2560 (D.C. Cir. May 31, 1956), rev'd en banc, unreported opinion reported in 26 U.S.L. WEEK 2169 (D.C. Cir. Oct. 3, 1957).

68. "That there is a social problem presented by obscenity is attested by the expression of the legislatures of the forty-eight States as well as the Congress. To recognize the existence of a problem, however, does not require that we sustain any and all measures adopted to meet that problem. ... Mistakes of the past prove that there is a strong countervailing interest to be considered in the freedoms guaranteed 
Finally, recurring again to the divisions of the Court in the Roth and Kingsley cases, it should be emphasized that changes in the substantive standard-along the line proposed-may be imperative in the interests of constitutionality.

\section{Administrative Problems and Proposals for Postal Censorship}

Until quite recently there has been doubt and dispute as to whether the decision-making process in postal censorship cases should work through formal, trial-type hearings. Indeed, back in 1940 the Attorney General's Committee on Administrative Procedures, when studying the Post Office Department, asked the question: Should the practice of obscenity censorship be formalized more than it is? Surprisingly, perhaps, the answer was "no." ${ }^{69}$

Formal hearings would be a waste of time, said the committee. The only real controversy in these cases has to do with characterization of the work in question. Is it "obscene"? You answer this question by inspecting-contemplating-the work and by making your best personal estimate. What good will a trial with a "parade of witnesses" do? For sincere witnesses can be found to argue either side of the question. Obscenity being "largely a question of one's own conscience," the Government ought to be primarily concerned about whose conscience will do the deciding, rather than the formalities of procedure. Thus, the key to good decision-making was a broadly trained "expert-a man schooled in the arts and sciences who would help the Department establish overall policies, criteria, and resolve hard cases. Look at the success of the Bureau of Customs, said the committee. It holds no hearings. But it does use an "expert" as an advisor. Controversy has been stilled. Do likewise, was the committee's advice to the Department. ${ }^{70}$

The Post Office rejected this advice. And within a decade, the courts, presumably disagreeing with arguments to the effect that hearings were wasteful and useless, began insisting that postal censorship decisions be rendered through the machinery of administrative trials in

by the first and fourteenth amendments. The line dividing the salacious or pornographic from literature or science is not straight and unwavering. ... It is manifest that the same object may have a different impact, varying according to the part of the community it reached. . . The conduct of the defendant is the central issue, not the obscenity of a book or picture. The nature of the materials is, of course, relevant as an attribute of the defendant's conduct, but the materials are thus placed in context from which they draw color and character. A wholly different result might be reached in a different setting." (Emphasis added.) Roth v. United States, 345 U.S. 476, 495 (1957).

69. See The Post Office Departanent 29-33, 95. Cf. Judge Arnold's opinion in Walker $v$. Popenoe: "The determination of whether a publication violates [the obscenity] standards is certainly one which should not be undertaken without a hearing." 149 F.2d 511, 514 (D.C. Cir. 1945).

70. The Post Office Department $31,33,45$. 
contested cases. ${ }^{71}$ Thus, the prescription of the Attorney General's Committee-add experts, not trials, to the decision-making processhas been taken in reverse dosage.

The fact is that both prescriptions seem like good advice. Utilization of "literary" or "scientific" "experts" in some cases may be most helpful to a lawyer who must determine whether a work, about which he may know very little, meets the elusive definition of obscenity. And certainly hearings should be essential if a conduct element is made a part of the censorship standard. "Inspection" 72 and abstract evaluation of the materials involved is not enough; just as important are the facts and legal conclusions to be drawn therefrom, relating to the respondent's use of the materials. In contested cases these should be adduced via adversary proceedings.

The more difficult issue today is whether there should be hearings first, prior to any stoppage of mail. In 1945, in Walker v. Popenoe, ${ }^{73}$ the court of appeals held that "due process" of law requires the Department to let allegedly obscene mail go through, unless and until the Department first determines, via formal, trial-type hearings that the work is "obscene." To the contention that this ruling would completely frustrate civil enforcement of the Comstock Act, Judge Arnold replied, in effect: then so be it; the remedy is to use the criminal sanctions of the statute.

Judge Arnold's admonition went unheeded. The Department continued to stop suspect mail summarily-even though, on several occasions, federal judges enjoined postal orders entered pursuant to this modus operandi.74 But very recently the court of appeals, en

71. See Pike v. Walker, 121 F.2d 37, 39 (D.C. Cir. 1941) ; Walker v. Popenoe, 149 F.2d 511 (D.C. Cir. 1945). Cf. Cates v. Haderlein, 342 U.S. 804 (1951); Door v. Donaldson, 195 F.2d 764 (D.C. Cir. 1952). But see Justice Douglas' opinion in the stay proceedings in Standard v. Olesen, 74 Sup. Ct. 768 (1954); Note, Postal Sanctions: A Study of the Summary Use of Administrative Power, 31 Ind. I.J. 257 (1956).

72. Cf. Door v. Donaldson, 195 F.2d 764 (D.C. Cir. 1952), holding that the Administrative Procedure Act's exemption of "proceedings in which decisions rest solely on inspections," 5 U.S.C. $\S 1008$ (1952), does not apply to postal obscenity determinations.

73. 149 F.2d 511, 514 (D.C. Cir. 1945). The Popenoe rule has, presumably, now been reappraised by the full bench of the court of appeals in Sunshine Book Co. v. Summerfield, 26 U.S.L. WEEK 2169 (D.C. Cir. Oct. 3, 1957). See note 1 supra.

74. See DeGrazia, supra note 9, at 610. In recent (December 1955) unreported litigation, the Post Office directed the local postmaster of Mount Morris, Ill., to hold up dispatch of a forthcoming issue of Confidential magazine and refer a sample copy to Washington for inspection. The postmaster complied. The issue was found "obscene." Confidential demanded a hearing on the merits, and pending that hearing, demanded that the Department deliver the issue to its subscribers. The district court granted this relief. More recently, similar unreported cases have been litigated involving Playboy and Rogue magazines. In each case the publication secured an injunction prohibiting interference with the mailing until the Department ruled the magazine "obscene" after a formal hearing complying with the Administrative Procedure Act. Information relative to these cases and pleadings and copies of the court orders were furnished by counsel for the magazines. 
banc, rendered its decision in Sunshine Book Co. v. Summerfield, and the status of the Popenoe doctrine is now hard to determine. ${ }^{75}$

The Sunshine Company is a publisher of nudist magazines, and thus a perennial opponent of the Department. Some time ago postal lawyers in Washington determined that forthcoming issues of these magazines were "obscene," and the local postmaster was told to "withhold" them "from dispatch" to subscribers. Sunshine was offered a prompt hearing under the Administrative Procedure Act, which resulted in entry of a formal decision, exculpating the text and message of the magazines but finding various pictures of practicing nudists "obscene"-a violation of the "community standard." Sunshine went to court to fight the nonmailability order on its merits, to challenge the constitutionality of the substantive censorship powers exercised by the Department and also the procedures used to enforce them-particularly the Department's apparent failure to comply with the "due process" doctrine laid down in Popenoe.

A divided court of appeals, overruling the initial decision of its panel, upheld the postal order in all respects. The constitutionality of censorship, exercised (as was the case here) wholly independently of criminal enforcement was sustained on the assumption that Roth and Kingsley have settled that issue-with little or no analysis of any possible constitutional distinction between civil and criminal enforcement of the Comstock Act. The procedures used by the Post Office to stop mail in transit, pendente lite, were expressly approved; curiously, Judge Danaher, writing for the majority, made no reference whatsoever to the Popenoe doctrine, neither distinguishing nor overruling it. But the three dissenters did, reasserting their belief in its wisdom, validity and applicability to the proceedings at hand.

It remains to be seen whether, in light of this decision, Walker $v$. Popenoe will become an obsolete relic. Obviously the matter is of extreme importance.

Indeed, it seems that this so-called "due process" problemwhether the Constitution permits the Post Office to stop mail summarily, prior to any hearing on the merits of the legality of the mailing-is in part another way of framing the issue of whether civil enforcement of the Comstock Act squares with first amendment freedoms. Reappraisal of the Popenoe doctrine ought to proceed in that context. For if it is assumed that censorship, confined to bans on certain kinds of illegal circulations is not automatically a violation of the first amendment, then the procedural requirements of "due process"

75. Sunshine Book Co. v. Summerfield, 26 U.S.L. W 2169 (D.C. Cir. Oct. 3, 1957). See note 1 supra. 
should hardly be so inexorable to deny the Government minimal power to do the job which Congress has legitimately asked it to do.

But "due process" should require that the Post Office keep interference with mail pendente lite, at a minimum. Obviously holding back the current issue of a magazine from its subscribers before its publisher has been given any opportunity whatsoever to defend himself against the charge that he has violated the law, is a serious matter. Just as with the substantive standard, so with procedure, a compromise is needed.

Thus, it is suggested that the Department should not stop delivery of the mail pendente lite, unless the violation is palpably serious ("seriousness" to be judged by the substantive criteria already suggested $)^{76}$ or unless criminal proceedings are initiated contemporaneously or unless the Department is confronted with a pattern of repeated violations. At the same time any aggrieved publisher ought to be given a right to go into court for an injunction restraining temporary stoppage in cases where the Department has either delayed its hearings unreasonably or in cases where, on the merits, it appears that the Government has abused its discretion by resort to this special remedy. Perhaps too, where the Department does seek to stop mail summarily, pending hearings on the merits, it should be required to initiate proceedings before its hearing examiner, e.g., in the form of a "show cause" order, which would establish proof in the nature of "probable cause" to justify this summary action.

Admittedly all this leaves considerable discretion to the administrators. At the same time the full rigor of the Popenoe doctrine must be modified if the Post Office is to have a non-mailability sanction at all. The courts could develop the flexible approach suggested above, in the absence of statutory change, indeed perhaps better without statutory change. And the Sunshine decision hardly forecloses this evolution. Rather it invites it.

Which introduces another question: What should be the scope of judicial review in postal cases? There is language in some of the cases to the effect that the courts ought only to set aside postal censorship orders where there has been an "abuse of discretion." 77 This view seems wrong, ${ }^{78}$ particularly if a conduct element is to be put into the

76. See text at note 65 supra. Compare Pub. I. No. 821, 84th Cong., 2d Sess. \$ 755 (July 27, 1956) which deals with the "mail block" sanction (amending 39 U.S.C. § 259 (a) (1952)) and which authorizes impounding pendente lite non-copyrighted materials after special notice and interlocutory hearings at the administrative level.

77. See, e.g., Roth v. Goldman, 172 F.2d 788 (2d Cir. 1949).

78. Cf. Parmelee v. United States, 113 F.2d 729, 731 (D.C. Cir. 1940); ALI, op. cit. supra note 43 , at 46 . 
substantive standard. Perhaps the agency's findings on purely factual matters-for example, the fact of mailing, the size and nature of the audience circularized-should stand where the record adduced at the administrative hearing supports them. But not its conclusions on the "obsceneness" of the challenged work, or whether mail distribution, under the circumstances, would be illegal. As Justice Brennan's majority opinion in the Roth case makes clear, the validity of antiobscenity laws is in part dependent on the fact that the courts can practice "ceaseless vigilance" to make sure that the standards are not abused. ${ }^{79}$

Indeed, in view of the precarious validity of censorship under the first amendment, it seems desirable, not only that court review be de novo, but that publishers be entitled to a jury trial if they so wish. While from a statistical viewpoint it is nonsense to say that a jury's verdict reflects the sense of a community, it is at least true that adding the jury trial ingredient increases the potential braking power of the law to stop abuses. If the objective is to confine censorship to the more serious cases, then civil enforcement should be virtually as accountable to the courts as is criminal enforcement. Unfortunately the proposal for jury trials on review of postal cases, unlike others put forth here, would seem to require new enabling legislation.

Another administrative problem relates to the mail block sanction, an indispensable weapon of postal censorship. Aside from criminal prosecution there is no other way to deal, effectively, with the commercial peddler of obscenity who sends both his "come-ons" and his wares under the privacy of the seal. ${ }^{.0}$ At the same time the possibilities for agency abuse of this sanction are obvious. Unless this postal power is limited, sedentary, responsible enterprises can in theory be threatened with business failure on the basis of a single mailing deemed unlawful, and this via an administrative proceeding-a glaring form of "prior restraint." 81 The revised substantive standard suggested above should

79. Roth v. United States, 345 U.S. 476 (1957).

80. Postal officials cannot and do not open sealed, first class mail without search warrants. This is a fourth amendment limitation. Ex parte Jackson, 79 U.S. 727 (1878). See 18 U.S.C. \& 1717 (1952). On the importance of the "mail block" sanction as a weapon of civil anti-obscenity enforcement, see the Government's petitions for certiorari to the Supreme Court in Summerfield v. Sunshine Book Co., No. 655, 1954 Term; Summerfield v. Tourlanes Publishing Co., No. 347, 1956 Term; letter of the Postmaster General in support of enactment of 39 U.S.C. $\$ 259$ a (1952), reprinted in S. REP. No. 2179, 81st Cong., 2d Sess. (1950).

81. Compare the "prior restraint" problems in connection with revoking permanent second class mail permits. See the dissents of Holmes and Brandeis in Milwaukee Publishing Co. v. Burleson, 255 U.S. 407, 417, 436 (1921).

While use of the mail block sanction has largely been confined to mail-order business in pictorial matter, the sanction can be used against books. See Cadillac Publishing Co. v. Summerfield, 227 F.2d 29 (D.C. Cir. 1955) (involving an encyclo- 
help to control use of the mail block sanction. So, too, court insistence on formal administrative proceedings should deter hasty, ill considered action. But there is also the matter of the scope of the remedy.

Ideally, the mail block sanction should be confined to stoppage of only incoming mail related to dissemination of the "obscene" matter. There should be no interference with the continued publication and distribution of any non-obscene work. A bookseller should not be deprived of all mail delivery just because one book he sells is "obscene." The courts, of course, beginning with an earlier Sunshine Magazine case (not to be confused with the very recent decision discussed above) have so interpreted the mail block statute, apparently to save its constitutionality. $^{82}$

But this rule (stop only incoming mail "related to" the illegal distribution) is easier to state than to enforce in practice. It seems administratively impossible to screen and segregate most first class mail this way. And a hard problem is what to do about the incoming mail of a dealer in obscene pictures who also conducts-but only as a "front" operation-a mail order business in innocuous matter. For example many "stag" movie distributors, advertising for mail order customers in "girlie" magazines, purport to sell "family" and "children's" movies as well as films "for men only." A pin-up magazine is an unlikely place to find customers for movies for tots, and judging from the tone and emphasis of many ads, it is doubtful if many of these distributors are really in business to serve the very young, rather than the prurient.

In cases of this sort, where the Government proves as part of its case that a substantial segment of the offender's merchandise is obscene matter, perhaps the answer is to permit the Post Office to hold up all mail except that which, on the face, of the envelope, is presumptively unrelated to the illegal enterprise, e.g., at the same time, in such a case,

pedia of sex). The Department, in 1949, found Gershorn Legman's Love and Death obscene, and brought proceedings which forced Legman to abandon a publishing business set up to sell it. An Oklahoma politician ("Cowboy Pink" Williams) was put out of business in 1953 when he attempted to sell a postcard with this message: "Cattlemen's Convention and Public Ass-Kicking-All Day Picnic at the head of Salt Creek the day after you are foreclosed. All cattlemen who voted for Ike will have their ass kicked free and all the crow they can eat." Information on these cases derived from files of American Civil Liberties Union in New York; see also In re Pink, Hearing Examiner Docket No. 2/207 for the Post Office record of this case; Williams v. Petty, 136 F. Supp. 283 (E.D. Okla. 1953) (does not deal with merits).

82. See Summerfield v. Sunshine Co., 221 F.2d 42 (D.C. Cir. 1954), cert. denied, 349 U.S. 921 (1955); Tourlanes Publishing Co. v. Summerfield, 231 F.2d 773 (D.C. Cir. 1955), cert. denied, 352 U.S. 912 (1956); Glanzman v. Finkle, 150 F. Supp. 823 (S.D.N.Y. 1957). As these cases indicate, the Department has found it very difficult to comply with the Sunshine rule. (And see the petitions for certiorari in Stunshine and Tourlanes, supra note 80). Until very recently, despite its reiteration in Tourlanes, the practice was to hold up all mail except mail which on its face was not related to the unlawful enterprise. 
the addressee could be given the alternative of (1) appearing at the post office and opening and withdrawing mail discovered to be unrelated to the obscenity enterprise, or (2) signing an affidavit pledging discontinuance (or temporary discontinuance, pending further litigation) of the illegal activity. The only other course of action seems to be strict enforcement of the Sunshine rule on mail blocks. But this means that the mail block sanction might well become useless and censorship impotent to do its job. And if we assume, as it now is the case, that criminal sanctions are not enough to control existing, noxious mail order commerce in obscenity, then some leeway must be left to the Department to use the necessary civil sanctions.

Finally, one more proposal relating to the administration of postal censorship: The Department should let the public know more about what it is doing. Today no one can learn much about the scope of the operation unles he consults formidable files in the hearing examiner's office (which are open to public inspection), or secures permission to consult the solicitor's non-mailability files (which are confidential). There is too much at stake here, too much controversy and misunderstanding to permit any sort of "secrecy"-even secrecy which is not at all contrived by the Government. This is especially true when we recognize that we are dealing with law which is in a state of flux, concepts which have been subject to rapid change over the past two or three decades. A full disclosure of what goes on, possible by means of full elaboration in the Postmaster General's Annual Report would seem in order.

\section{A Suggested Approach to Customs Censorship}

The proposals advanced have thus far dealt only with postal censorship. Customs enforcement of the Tariff Act must be considered apart. For foreign "exploiters" present a serious problem-both in terms of the erotic or pornographic nature of the works they offer and in terms of the ease with which they could reach the United States market if left uncontrolled. The rub is that these disseminators are beyond the reach of our laws. Direct action cannot be taken against them, and the only effective way to stop foreign commercial exploitation-assuming it is to be stopped-is to screen all obscenity coming into the country. Unfortunately this results in precisely the kind of total censorship which has been criticized herein-for example, denial of Lady Chatterly to mature adult readers. However, that result might be tempered if the Tariff Law's existing loophole-discretionary releases-were widened by liberalization of the standards and procedures for release. 
Here are some changes which might well be beneficial. Some, unfortunately, would require new legislation.

(a) Exercise of the release power through procedures fairer to importers. This would probably encourage more petitions and more releases. A basic reform, which requires no legislation, would be simply, to notify importers of their right to petition for release, giving full explanation of what the law allows. ${ }^{83}$ Indeed, it seems hard to justify the present failure to supply such notice. There should also be the right to a hearing - a chance for the importer to appear personally and defend his claim to exemption. The precise degree of formality which should attend these hearings may be a matter of doubt but at the very least the importer should be entitled to counsel and witnesses, and be allowed to introduce evidence. The decision itself, and the reasons to support it, should be a matter of public record.

(b) The present administrative interpretation of the tariff statute to the effect that the work must have established recognition in this country should be revised. This has resulted in refusals to permit entry of rare orientalia of the works of American authors like Henry Miller. It seems indefensible that mature Americans can't study literature or art which is accepted (and perhaps even widely praised) for its merit in other cultures or countries.

(c) Broaden the concept of what constitutes a work of "merit." The probable intent behind the existing exemption was to promote study of books and works of art for literary, educational or scientific purposes regardless of their obscenity. That intent should be effectuated, either by legislative amendment or by administrative interpretation of the existing release power. The point is that "merit" should be judged in light of the purpose for which the work is imported. If a book has value to an importer's interests, and if these interests are not harmful, then release it to him. ${ }^{84}$

(d) Any adult with a mature interest in the work should have standing to petition for release. The Bureau, as noted, seems to stress special, formal, for example, scholarly, credentials. But it should be

83. When the Bureau detains an import on grounds of its alleged obscenity, the importer is notified by the collector and asked to sign an enclosed assent to forfeiture of the materials. Forms for these "notices" vary locally, but none really advise the importer of his rights: (1) to a court proceeding, de novo, with the right to jury trial with burden of proof on the Government. (This court proceeding is required by the Tariff Act of 1930, 46 STAx. 688, 19 U.S.C. $\S 1305$ (a) (1952)); (2) to petition the Secretary of Treasury, in his discretion, to release the work. See notes 22 and 28 stipra.

84. See note 31 supra. Cf. United States v. One Unbound Volume, $128 \mathrm{~F}$. Supp. 280 (D. Md. 1955) (Seizure of a folio of plates and pictures depicting Roman and Etruscan vases, some of which were decorated with erotic drawings upheld by district court on the ground that these pictures, if displayed publicly, would violate the "com- 
enough that the petitioner furnish credible assurance of his maturity, and a plausible explanation of his motivation for purchasing the work. This explanation should be judged in the context of the nature of the obscene work. It would obviously take a lot more to justify release of pure pornography, though special cases justifying this can be conjured-e.g., Kinsey's. On the other hand it ought not to take much to justify release, to a mature adult, of a work like Lady Chatterly, or a rare edition of the Decameron seized because of its illustrations.

(e) The law now says no releases of "commercial" importations. This is too broad; it smacks of the "universal" blanket ban, condemned so vigorously by Justice Harlan. A reputable bookstore importing limited quantities of Lady Chatterly ought to be allowed to do so. After all, the store's subsequent reselling of the work can be policed. The prospect of harm here is certainly slight, especially if the importer furnishes, by affidavit, credible statements explaining why the work is to be imported, how and to whom he expects to sell it.

(f) Release of movies, imported commercially by bona-fide distributors, should be permitted. Indeed, there is a serious problem as to whether the United States should go on censoring foreign movies at all. Of course, obscene commercial movies can be commercially exploited. But whatever exploitation goes on, goes on quite in the open. And state and local law enforcement should be able to handle this problem without Uncle Sam's censorial help. Granting that existing federal censorship is now kept at a minimum, it also is true that standards for judging "obsceneness" in movies can often be most diffcult to apply. The Bureau today cuts out scenes which it thinks offend some community standard on acceptability. It assumes a single national standard, but pretty clearly there is none, for acceptability in movies may vary, not only from place to place, but-depending on which theatres exhibit the film and how they advertise it-whether the film's "obsceneness" is exploited or treated with discretion. Moreover, while the impact of customs censorship today is very slight, there is no assurance that tomorrow's officials will be so tolerant. At least when a reputable importer brings in a film which has some aritistic backing, it would seem that the need for Bureau scissoring is not so overriding that a reputable importing distributor, given a warning, shouldn't be allowed to take his chances with enforcement of local laws.

munity standard." Actually the plates were consigned to an amateur anthropologist who, prior to the court case, had requested a special exception. The Bureau, without disclosing its reasons or inviting any further showing by way of a more formal "petition" for release, refused to release the work. Supplemental information including copies of correspondence to and from the Bureau has been furnished by the importer who appeared pro se in all proceedings). 
(g) The Bureau's refusal to release should also be reviewable in the courts-just as its seizures are-both to insure against the obvious possibility of abuse and to provide an incentive to the Bureau to be liberal about using it.

(h) Finally-and most important: There should be full disclosure to the public at large about the Bureau's censorship operations. Today, the Bureau suppresses this information on the grounds that some of the more prurient among us might get curious and attempt to import books which we have ruled obscene. But the names of many of these books could probably be obtained if one is curious enough to make the inquiry. The Library of Congress makes some of this "obscenity" available to the public. But more to the point: this secrecy is undemocratic. Grant that today Bureau enforcement of the Tariff Act is conscientious, careful and perhaps praiseworthy: Who is to say what will happen tomorrow? Moreover, closing the censorship records to public inspection shuts off information which is essential to rational investigation of the desirability of the operation. Not only should these records be open to reasonable inspection, but the essential information should be made more available to the public, perhaps through the Secretary of Treasury's Annual Report.

Even with all these proposals, the release power poses vexing questions. The trouble of course, is that there are few objective standards to guide those who must make the decisions. And just as Senator Johnson ridiculed the exemption when Senator Smoot first proposed it back in 1930, so it is easy to sneer at proposals for making the loophole bigger.

But, if one accepts the basic principles for a compromise solution to the problem of obscenity which are the underlying premises of this proposal, the overriding question becomes: are any of the other answers to the importation problem more acceptable? The only alternative is abolishing control of all private importation. That may well be a worthwhile, long-range goal. But it is probably unrealistic today. At least broadening the release power should be attempted as an experimental, evolutionary step. The pending litigation between Indiana University and the United States Government over seizure of Professor Kinsey's research material may well force reappraisal and a more flexible program. The proposals above would permit greater freedom to read, greater freedom of access to books of one's choice and, at the same time, permit continued government surveillance of importation to check noxious foreign commercial exploitation within our borders. 